\title{
Detailed Visual Cortical Responses Generated by Retinal Sheet Transplants in Rats with Severe Retinal Degeneration
}

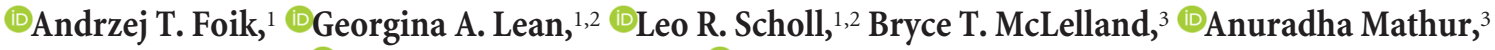 \\ Robert B. Aramant, ${ }^{3}{ }^{\circledR}$ Magdalene J. Seiler, ${ }^{3}$ and ${ }^{-D a v i d ~ C . ~ L y o n ~}{ }^{1}$ \\ ${ }^{1}$ Department of Anatomy and Neurobiology, School of Medicine, University of California-Irvine, Irvine, California 92697-1275, ${ }^{2}$ Department of Cognitive \\ Sciences, School of Social Sciences, University of California-Irvine, Irvine, California 92697-5100, and ${ }^{3}$ Department of Physical Medicine and \\ Rehabilitation, School of Medicine, University of California-Irvine, Irvine, California 92697-1705
}

To combat retinal degeneration, healthy fetal retinal sheets have been successfully transplanted into both rodent models and humans, with synaptic connectivity between transplant and degenerated host retina having been confirmed. In rodent studies, transplants have been shown to restore responses to flashes of light in a region of the superior colliculus corresponding to the location of the transplant in the host retina. To determine the quality and detail of visual information provided by the transplant, visual responsivity was studied here at the level of visual cortex where higher visual perception is processed. For our model, we used the transgenic Rho-S334ter line-3 rat (both sexes), which loses photoreceptors at an early age and is effectively blind at postnatal day 30 . These rats received fetal retinal sheet transplants in one eye between 24 and $40 \mathrm{~d}$ of age. Three to 10 months following surgery, visually responsive neurons were found in regions of primary visual cortex matching the transplanted region of the retina that were as highly selective as normal rat to stimulus orientation, size, contrast, and spatial and temporal frequencies. Conversely, we found that selective response properties were largely absent in nontransplanted line-3 rats. Our data show that fetal retinal sheet transplants can result in remarkably normal visual function in visual cortex of rats with a degenerated host retina and represents a critical step toward developing an effective remedy for the visually impaired human population.

Key words: neurophysiology; orientation selectivity; primary visual cortex; visual cortex; visual pathway; visual rehabilitation

Significance Statement

Age-related macular degeneration and retinitis pigmentosa lead to profound vision loss in millions of people worldwide. Many patients lose both retinal pigment epithelium and photoreceptors. Hence, there is a great demand for the development of efficient techniques that allow for long-term vision restoration. In this study, we transplanted dissected fetal retinal sheets, which can differentiate into photoreceptors and integrate with the host retina of rats with severe retinal degeneration. Remarkably, we show that transplants generated visual responses in cortex similar in quality to normal rats. Furthermore, transplants preserved connectivity within visual cortex and the retinal relay from the lateral geniculate nucleus to visual cortex, supporting their potential application in curing vision loss associated with retinal degeneration.

\section{Introduction}

Millions of people worldwide suffer vision loss from progressed stages of age-related macular degeneration and retinitis pigmen- tosa. Through either disease, much of the retinal pigment epithelium (RPE) and many photoreceptors are irreversibly lost. Cutting edge treatments using micronutrient supplements (Berson et al., 2004) and gene therapy to introduce trophic factors or to correct mutated genes (M. M. Liu et al., 2011b; Kauper et al., 2012; Lipinski et al., 2013; Bertolotti et al., 2014; Schwartz et al., 2015; Tsai et al., 2015) can help in the early stages of retinal degeneration where some photoreceptors remain and can therefore be rescued. However, in later stages, once photoreceptors

\footnotetext{
Received May 21, 2018; revised 0ct. 18, 2018; accepted 0ct. 21, 2018.

Author contributions: A.T.F. wrote the first draft of the paper; G.A.L., L.R.S., B.T.M., A.M., R.B.A., and M.J.S. edited the paper; A.T.F., M.J.S., and D.C.L. designed research;A.T.F., G.A.L., L.R.S., B.T.M., A.M., M.J.S., and D.C.L. performed research; B.T.M., A.M., R.B.A., and M.J.S. contributed unpublished reagents/analytic tools; A.T.F., G.A.L., L.R.S., B.T.M., A.M., R.B.A., M.J.S., and D.C.L. analyzed data; D.C.L. wrote the paper.

This work was supported by California Institute for Regenerative Medicine TR4-06648 to M.J.S., Whitehall Foundation 2014-08-100 to D.C.L., and National Eye Institute R01EY024890 to D.C.L.

The authors declare no competing financial interests.

Correspondence should be addressed to Dr. David C. Lyon, University of California, School of Medicine, 364 Med Surge II, Irvine, CA 92697-1275. E-mail: ddlyon@uci.edu.
}

https://doi.org/10.1523/JNEUROSCl.1279-18.2018

Copyright $\odot 2018$ the authors $\quad 0270-6474 / 18 / 3810709-16 \$ 15.00 / 0$ 
and RPE cells are lost, vision can only be enabled by replacing or bypassing damaged retinal cells.

To replace lost photoreceptors in rodent models of severe retinal degeneration, Rho-S334ter line-3 rats, a number of studies have successfully used sheet transplants of fetal-derived neural retinal progenitor cells into the subretinal space (Seiler et al., 2005, 2008a, 2014). The fetal retinal sheet transplants survive long-term (Seiler et al., 1999), integrate with the host retina (Seiler et al., 2008b, 2010), and evoke responses to flashes of light in the superior colliculus, a primary midbrain target of retinal ganglion cells (Woch et al., 2001; Sagdullaev et al., 2003; Thomas et al., 2005; Yang et al., 2010). To determine the quality and accuracy of visual information provided by the transplant, visual responsivity should be measured in greater detail and in higher level structures, such as visual cortex where more complex visual processing occurs.

The visual environment is parsed into tiny receptive fields by the photoreceptors at the back of the retina. Restitching of the visual image begins through convergence and lateral integration across progressive stages of the retina and through subsequent retinal ganglion cell projections to the LGN of the thalamus. It is not until after LGN afferents converge onto neurons in primary visual cortex (V1) that key features, such as orientation selectivity, fully emerge, although in mouse LGN direction selectivity is already present (Hubel and Wiesel, 1962; Reid and Alonso, 1996; Niell and Stryker, 2008; Marshel et al., 2012). Many additional stimulus features, such as temporal and spatial frequency, contrast, size, and direction, also elicit highly selective responses in V1 and are considered key building blocks for the perception of complex shapes and motion (Livingstone and Hubel, 1988; Kobatake and Tanaka, 1994; Marshel et al., 2011; Glickfeld et al., 2014).

In the more severe and faster degenerating line-3 rat model, and even in the slower degenerating Royal College of Surgeons rat model, cortical responses to visual stimulation are almost entirely abolished in adults (Coffey et al., 2002; Girman et al., 2003; Gias et al., 2011; Chen et al., 2016), severely limiting normal visual perception. Our goal here was to determine whether retinal sheet transplants could generate visually evoked responses in visual cortex, and the degree to which detailed response selectivity compared with V1 neurons in normal, nondegenerated rats. To do so, healthy dissected fetal retinal sheets were transplanted in line-3 rats at 1 month of age, when degeneration of the rods is nearly complete and cones are largely dysfunctional (Hombrebueno et al., 2010; Martinez-Navarrete et al., 2011; Zhu et al., 2013; Seiler et al., 2014; LaVail et al., 2018). Three months or more following transplantation, detailed neuronal responses to an array of visual stimuli integral to higher visual processing were measured and compared with control degenerated animals that did not receive transplants, as well as nondegenerated rats. Comparisons in the underlying neural circuitry were also made by using injections of a modified rabies virus to reconstruct retrograde connection patterns within V1, and afferent thalamic inputs. These experiments are the first to examine transplant-driven responses and connectivity at the cortical level in a rodent model of retinal degeneration and represent an essential step for determining the efficacy of such transplants in visually impaired humans.

\section{Materials and Methods}

Animals. For all experimental procedures, animal subjects were treated in accordance with the National Institutes of Health Guide for the care and use of laboratory animals, the ARVO Statement for the Use of Animals in Ophthalmic and Vision Research, and under a protocol approved by the

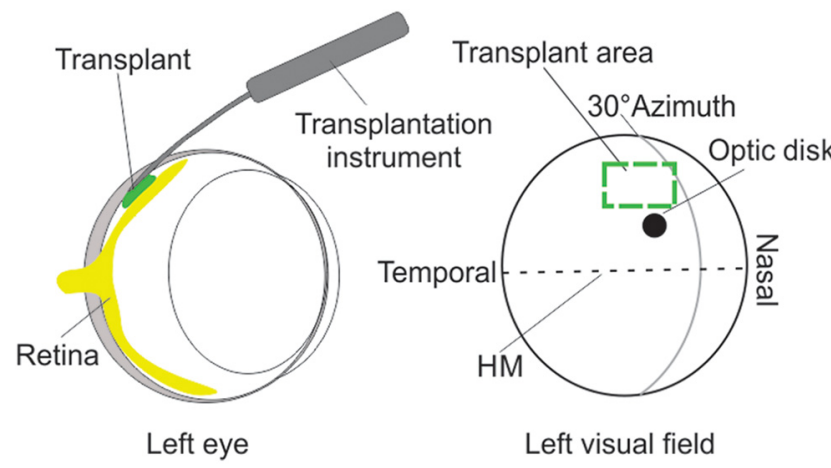

Figure 1. Diagram of experimental setup. A retinal sheet transplant derived from fetal transgenic rats is carefully placed in the subretinal space between host-degenerated retina and retinal pigment epithelium using a custom-made surgical tool (Left). The transplant is placed close to the optic disc in the upper temporal area of the visual field (Right). The horizontal meridian (HM) bisects the upper and lower visual field representations.

Institutional Animal Care and Use Committee of University of California-Irvine. The rat model of retinal degeneration used in this study was pigmented transgenic Rho-S334ter line-3 rats (or line-3 rats) expressing a mutated human rhodopsin protein (Sagdullaev et al., 2003; MartinezNavarrete et al., 2011; Seiler et al., 2017). Line-3 rats were non-nude $($ foxn $1+/)$ offspring of the SD-Foxn1 Tg (S334ter) 3Lav strain, a cross of S334ter-3 (SD-Tg(S334ter)3Lav) and NIH nude (NTac:NIH-Whn) rats (Seiler et al., 2014). Normal rats used for comparison were either the NIH or Long-Evans (see Results). In all groups, rats of either sex were used. All rats were group housed ( 4 animals per Plexiglas cage) and maintained in the animal facility on a $12 \mathrm{~h}$ light/dark cycle (lights on from 06:30 to 18:30 h) at an ambient temperature of $21.5 \pm 0.8^{\circ} \mathrm{C}$ and a relative humidity of $50 \%$.

Transgenic rats carrying the human placental alkaline phosphatase (hPAP) gene were used as the source of donor retinal sheet tissue. Donor rats were bred from transgenic rats positive for hPAP (Kisseberth et al., 1999; Yang et al., 2010; Seiler et al., 2017) (breeders originally a gift of Dr. Eric Sandgren, University of Wisconsin, Madison, WI) and ACI rats obtained from Harlan Laboratories. At day 19 of gestation (day of conception $=$ day 0$)$, fetuses were removed by cesarean section. Transgenic fetuses were identified by histochemistry for hPAP (Kisseberth et al., 1999) and were stored on ice in Hibernate E medium with B-27 supplements (Invitrogen) for up to $6 \mathrm{~h}$ until dissection. Retinas were dissected free from surrounding tissue and stored overnight at $4^{\circ} \mathrm{C}$ in $50-100 \mu$ l of Hibernate E medium with BDNF/GDNF-loaded PLGA microspheres (Seiler et al., 2008a; Yang et al., 2010). Retinal sheets were cut into rectangular pieces of $1.0-1.5 \times 0.6 \mathrm{~mm}$ to fit into the flat nozzle of the previously described custom-made implantation tool (Seiler and Aramant, 1998; Aramant and Seiler, 2002). The orientation of the donor tissue could easily be observed in the dissection microscope.

Transplantation procedure. The transplantation procedure was performed according to previously described methodology (Aramant and Seiler, 2002). Line-3 rats (P24-25) were anesthetized with a mixture of ketamine $(40-55 \mathrm{mg} / \mathrm{kg})$ and xylazine $(6-7.5 \mathrm{mg} / \mathrm{kg}$; i.p.). Their pupils were dilated with $1 \%$ atropine eye drops, and local anesthesia was provided by tetracaine eye drops $(0.5 \%)$. A small incision (width $1.0 \mathrm{~mm}$ ) was made posterior to the pars plana, parallel to the limbus. The implantation instrument was inserted with extreme care to minimize disturbance of the host retinal pigment epithelium. The graft tissue $\left(\sim 1 \mathrm{~mm}^{2}\right)$ was released into the subretinal space posteriorly at the nasal quadrant near the optic disc (Fig. 1). Transplants were placed into the left eye only, leaving the right eye as a control. The incision was closed with two 10-0 sutures, and the eyes were treated with gentamycin and artificial tears ointment. For recovery, rats were given a subcutaneous injection of Ringer's saline solution, the analgesic Buprenex $(0.03 \mathrm{mg} / \mathrm{kg})$ for pain management, and placed in a Thermocare incubator. Animals with transplant misplacement and/or excessive surgical trauma were excluded from study. 

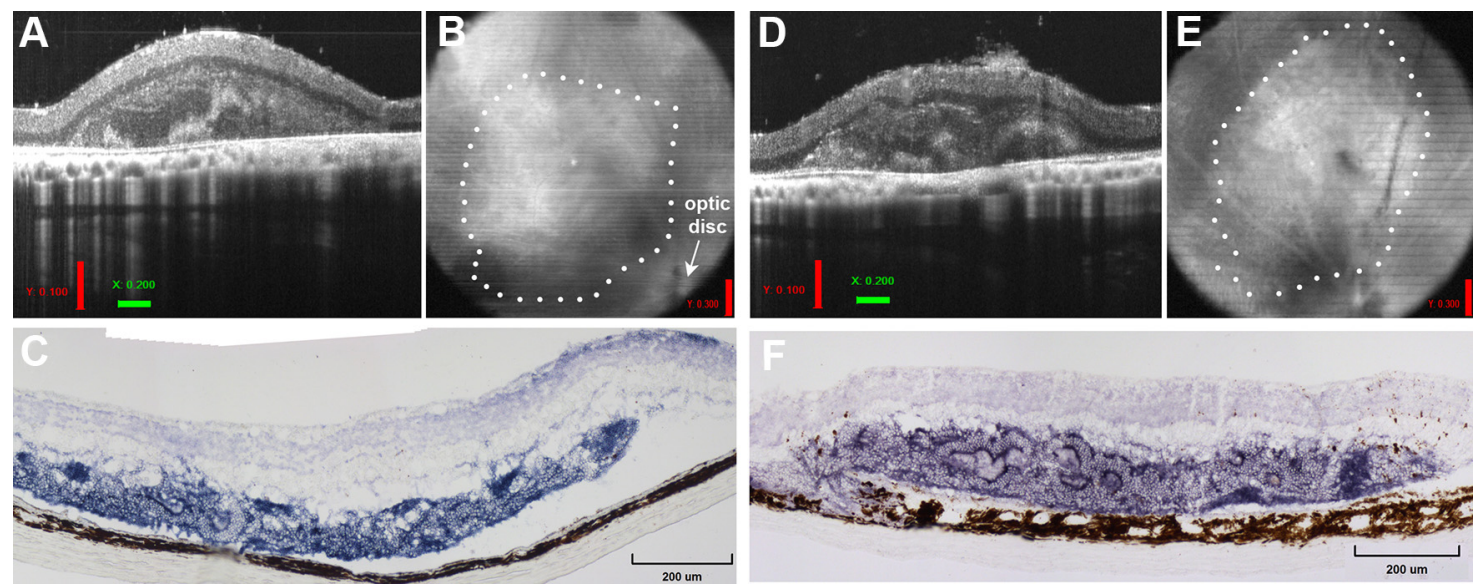

Figure 2. Retinal transplant can survive and integrate with degenerated host retina. Examples of retinal transplants verified in vivo by high-resolution $0 C \mathrm{CT}$ at $1 \mathrm{month}$ after surgery are shown for Rats R15-13 $(\boldsymbol{A}, \boldsymbol{B})$ and R15-15 $(\boldsymbol{D}, \boldsymbol{E}) . \boldsymbol{A}, \boldsymbol{D}, \mathrm{B}$ scans show the transplant placement in the subretinal space. Regions with partial lamination are clear in addition to photoreceptor rosettes. $\boldsymbol{B}, \boldsymbol{E}$, Fundus images represent the transplant placement nasal-dorsal to the optic disc. $C, F$, Examples are shown of BCIP staining for human placental alkaline phosphatase (dark blue to purple) labeling donor tissue in the subretinal space at 4.4 months $(\boldsymbol{C})$ and 3.5 months $(\boldsymbol{F})$ after surgery in Rats R15-13 and R15-15, respectively. Dark blue visible beyond the transplant represents cells that migrated from fetal tissue and continued to develop within the host retina.

Transplant verification. Transplants were evaluated in vivo for placement, development, and integration within the host retina $\sim 1$ month after surgery by using spectral domain optical coherence tomography. Spectral domain optical coherence tomography images of the retina were obtained using an Envisu R2200 Spectral Domain Ophthalmic Imaging System (Bioptigen). Anesthesia was induced with ketamine/xylazine as above and maintained using isoflurane $(0.5 \%-1.5 \%)$ mixed with $\mathrm{O}_{2}$ through a gas anesthesia mask (Stoelting). Pupils were dilated by $1 \%$ atropine sulfate ophthalmic solution. Eyes were kept moist between scans with Systane eye drops (Alcon Laboratories). Imaging was accomplished using rectangular scans of a $2.6 \mathrm{~mm} \times 2.6 \mathrm{~mm}$ area at an imaging depth of $1.6 \mathrm{~mm}$. Retina fundus scans were acquired using at least one of four parameters: 488 B scans $\times 488$ A scans $\times 5$ B scan averaging for fundus images; and $700 \times 70 \times 25,800 \times 50 \times 30$, and $800 \times 20 \times 80$ for cross-sectional images (units are no. of B scans/no. of A scans/ B scan averaging value). A scans were performed along the fundus axial plane. Each A scan was then further probed by B scans to create the crosssectional visualization of the retinal layers. B scans were then averaged together to reduce background speckle and improve resolution of low contrast and hard-to-see layers; the larger the B scan averaging value, the better the resolution. The optic disc was centered and used as a point of reference for locating the transplant and assessing surgical success.

Single-unit recordings and visual stimulation. Rats were initially anesthetized with $2 \%$ isoflurane in a mixture of $\mathrm{N}_{2} \mathrm{O} / \mathrm{O}_{2}(70 \% / 30 \%)$ and then placed into a stereotaxic apparatus. A small, custom-made plastic chamber was glued to the exposed skull. After $1 \mathrm{~d}$ of recovery, reanesthetized animals were placed in a custom-made hammock, maintained under isoflurane anesthesia $\left(1 \%-2 \%\right.$ in mixture of $\left.\mathrm{N}_{2} \mathrm{O} / \mathrm{O}_{2}\right)$, and a single tungsten electrode was inserted into a small craniotomy above visual cortex. Once the electrode was inserted, the chamber was filled with sterile saline. During recording sessions, animals were kept sedated under light isoflurane anesthesia $(0.2 \%-0.4 \%)$ in a mixture of $\mathrm{N}_{2} \mathrm{O} / \mathrm{O}_{2}$. EEG and $\mathrm{EKG}$ were monitored throughout the experiments, and body temperature was maintained with a heating pad (Harvard Apparatus).

Data were acquired using a 32-channel Scout recording system. The spike signal was bandpass filtered from $500 \mathrm{~Hz}$ to $7 \mathrm{kHz}$ and stored in a computer hard drive at $30 \mathrm{kHz}$ sampling frequency. Spikes were sorted online in Trellis while performing visual stimulation. Visual stimuli were generated in MATLAB (The MathWorks) using Psychophysics Toolbox (Brainard, 1997; Pelli, 1997; Kleiner et al., 2007) and displayed on a gamma-corrected LCD monitor ( 55 inches, $60 \mathrm{~Hz}$ ) at resolution $1920 \times$ 1080 pixels and $52 \mathrm{~cd} / \mathrm{m}^{2}$ mean luminance. Stimulus onset times were corrected for LCD monitor delay using a photoresistor and microcontroller (in-house design).
For recordings of visually evoked responses, cells were first tested for visual responsiveness with 100 repetitions of a $500 \mathrm{~ms}$ bright flash stimulus $\left(105 \mathrm{~cd} / \mathrm{m}^{2}\right)$. Receptive fields for visually responsive cells were located using square-wave drifting gratings, after which optimal orientation/direction and spatial and temporal frequencies were determined using sine wave gratings. Spatial frequencies tested were from 0.001 to 0.5 cycles $/{ }^{\circ}$. Temporal frequencies tested were $0.1-10$ cycles/s. With these optimal parameters, size tuning was assessed using sizes of $1^{\circ}-110^{\circ}$, and $100 \%$ contrast. With the optimal size, temporal and spatial frequencies, and at high contrast, the orientation selectivity of the cell was tested again using 16 directions stepped by $22.5^{\circ}$ increments. This was followed by testing of contrast.

Virus injections. Upon completion of $\mathrm{V} 1$ recordings, a subset of rats were given injections of mCherry and/or GFP-expressing versions of a glycoprotein-deleted rabies virus (Wickersham et al., 2007a,b). Viruses were grown in the laboratory from existing stock and concentrated to a titer range of $\sim 5 \times 10^{9}$ infectious units $/ \mathrm{ml}$ following published protocols (Wickersham et al., 2010; Osakada et al., 2011). For injections, animals were anesthetized with isoflurane and placed in a stereotaxic head-holder. Under sterile conditions, the existing craniotomy from the recording procedure was accessed. Glass pipettes with tips broken to $\sim 20 \mu \mathrm{m}$ were filled with virus and inserted using a computercontrolled micro-positioner attached to a stereotaxic arm (Kopf). Pressure injections of $\sim 0.5 \mu \mathrm{l}$ were made at depths of $\sim 500$ and 1200 $\mu \mathrm{m}$ using a pico-pump. Following injections, artificial dura (Tecoflex, Microspec) was placed over the craniotomy, the skull sealed with dental acrylic, the animals revived and given a $7-10 \mathrm{~d}$ survival before perfusion and histology.

Histology. Upon completion of recordings and/or following virus injection survival time, animals were deeply anesthetized with Euthasol $(390 \mathrm{mg} / \mathrm{ml}$ of sodium pentobarbital and $50 \mathrm{mg} / \mathrm{ml}$ of sodium phenytoin; i.p.; Vedco) and perfused transcardially, first with saline and then with 4\% PFA in phosphate buffer (PB), $\mathrm{pH}$ 7.4. Brains were removed and cryoprotected in $30 \%$ sucrose for $\sim 48 \mathrm{~h}$ before sectioning. Eyes were also removed and postfixed in $4 \%$ PFA overnight.

Whole brains were cut coronally into $40 \mu \mathrm{m}$ sections and then mounted and coverslipped using PVA-DABCO to preserve rabies virus fluorescence. Brain sections were examined under fluorescent microscopy (Carl Zeiss Axioplan) with $10 \times(0.45 \mathrm{NA})$ objectives where rabiesinfected cell positions were reconstructed using Neurolucida software (MicroBrightField). To limit bleaching of fluorescence, analysis was done offline. Images of whole sections were captured with a high-power black and white digital camera (SensiCam QE, Cooke) and stitched together through the Virtual Slide module. For each animal, one of every 

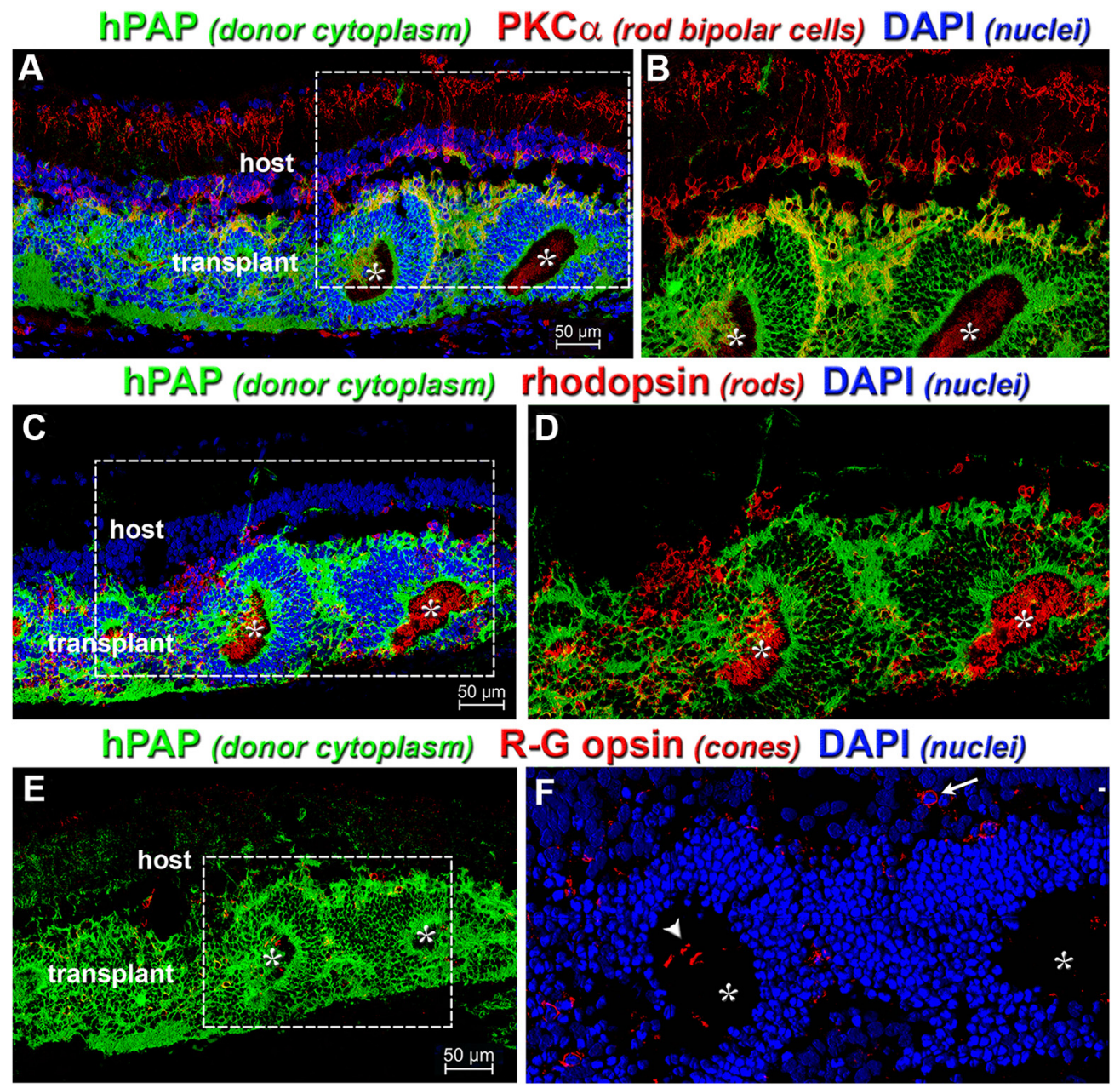

Figure 3. Retinal transplants generate new photoreceptors and rod bipolar cells. All images represent transplant at 3.5 months after surgery from Rat R15-15 and are oriented with ganglion cell side up and RPE side down. $A$, PKC $\alpha$ is a marker of rod bipolar cells and labels both the host (hPAP ${ }^{-}$, red) and donor (hPAP ${ }^{+}$, green) tissue. Donor bipolar cells (yellow) surround photoreceptor rosettes (white asterisks) and interact with photoreceptor terminals to form a putative outer plexiform layer. $\boldsymbol{B}$, Magnification of boxed region in $\boldsymbol{A}$ with blue channel removed. Donor bipolar cells (yellow) have synaptic projections that innervate the host inner plexiform layer. Without these connections, the photoreceptor light response will not be detected in the brain. $C$, Rhodopsin (Rho) expression within donor-derived photoreceptor rosettes. Rho ${ }^{+}$outer segments (red) are indicative of functional rods and critical for light response. D, Magnification of boxed region in $\mathbf{C}$ with blue channel removed. Rho is localized within rosettes and the photoreceptor cell bodies (green) surround the inward-pointing outer segments. $E$, Red-green (R/G) opsin (red) labels cone outer segments and is mostly found within donor rosettes. There are almost no host cones remaining. $\boldsymbol{F}$, Magnification of boxed region in $\boldsymbol{E}$ with green channel removed to allow R/G opsin signal to be more clearly seen. Cones are generated at a lower frequency than rods. Only transplant cones have outer segments (arrowhead). Arrow indicates remaining host cone.

four sections was used to identify the number of infected neurons in four visual structures: the LGN, lateral posterior nucleus (LP), V1, and higher visual cortex, confirmed through the atlas by Paxinos and Watson (2001). Based on these counts, the percentage of labeled cells found in each area was calculated for each case (see Results). In animals where both the GFP and mCherry-expressing rabies viruses were injected, infected cells were counted separately.

After washing with PB, eye cups were dissected along the dorsoventral axis, embedded in Tissue-Tek optimum cutting temperature compound (Sakura Finetek), and frozen in isopentane on dry ice. The $10 \mu \mathrm{m}$ sections were cut on a cryostat and stored at $-20^{\circ} \mathrm{C}$. Every fifth slide was analyzed for the presence of the transplant by staining with BCIP/NBT substrate (B1911; Sigma-Aldrich). BCIP/NBT-stained slides were imaged on an Olympus BXH10 (Olympus Scientific Solutions) using an Infinity 3-1U camera (Lumenera). For immunofluorescence, cryostat sections underwent antigen retrieval at $70^{\circ} \mathrm{C}$ with Histo-VT One (Nacalai) and blocked for at least $30 \mathrm{~min}$ in $10 \%$ donkey serum. Primaries were left on sections overnight at $4{ }^{\circ} \mathrm{C}$. Antibody vendor and concentration are as follows: rabbit $\alpha$-hPAP (1:200; Epitomics, Abcam), mouse $\alpha$-hPAP (1:25, clone A89; Thermo Fisher Scientific), mouse $\alpha$-PKC $\alpha$ (1:500; Stressgen Biotechnologies), rabbit $\alpha$-rhodopsin (1:100; kind gift of Dr. Robert Molday, University of British Columbia), and rabbit $\alpha$-red/green opsin (1:100; Millipore Bioscience Research Reagents, Fisher Scientific).
After several PBS washes, slides were incubated for at least $30 \mathrm{~min}$ at room temperature in fluorescent secondary antibodies: AlexaFluor-488 donkey anti-rabbit IgG $(\mathrm{H}+\mathrm{L})$, rhodamine $\times$ donkey anti-rabbit IgG $(\mathrm{H}+\mathrm{L})$, AlexaFluor-488 donkey anti-mouse $\operatorname{IgG}(\mathrm{H}+\mathrm{L})$, or rhodamine $\times$ donkey anti-mouse IgG $(\mathrm{H}+\mathrm{L})(1: 400$; Jackson ImmunoResearch Laboratories). Fluorescent sections were coverslipped using Vectashield mounting media (Vector Labs) with $5 \mu \mathrm{g} / \mathrm{ml}$ DAPI (Thermo Fisher Scientific). Fluorescence was imaged using an LSM700 confocal microscope (Carl Zeiss) taking tiled stacks of $5-8 \mu \mathrm{m}$ thickness at $40 \times$ (selected images). Zen 2012 software (Carl Zeiss) was used to extract confocal images. 3D images were extracted separately for each channel and combined in Photoshop CS6 software (Adobe).

Data analysis. Tuning curves were calculated based on average spike rate. Optimal visual parameters were chosen as the maximum response value. Orientation selectivity index (OSI) was calculated as follows (Cavanaugh et al., 2002; Hashemi-Nezhad and Lyon, 2012):

$$
O S I=\frac{\left|\sum_{n} R_{n} \exp \left(i \theta_{n}\right)\right|}{\left(\sum_{n}\left|R_{n}\right|\right)}
$$


where $\theta_{n}$ is the $n$th orientation of the stimulus and $R_{n}$ is the corresponding response.

For tuning width, the orientation responses were fitted to Gaussian distributions (Carandini and Ferster, 2000; Alitto and Usrey, 2004; Y. J. Liu et al., 2015, 2017) using the following:

$$
R_{0},=\text { baseline }+R_{p} e^{-\frac{\left(O_{s}-O_{p}\right)^{2}}{2 \sigma^{2}}}+R_{n} e^{-\frac{\left(O_{s}-O_{p}+180\right)^{2}}{2 \sigma^{2}}}
$$

where $O_{s}$ is the stimulus orientation, $R_{O s}$ is the response to different orientations, $O_{p}$ is the preferred orientation, $R_{p}$ and $R_{n}$ are the responses at the preferred and nonpreferred direction, $\sigma$ is the tuning width, and baseline is the offset of the Gaussian distribution. Gaussian fits were estimated without subtracting spontaneous activity, similar to the procedures of Alitto and Usrey (2004). The orientation tuning bandwidth of each tuning curve was measured in degrees as the half-width at halfheight $(\mathrm{HWHH})$, which equals $1.18 \times \sigma$ based on the equation above.

Size tuning curves were fitted by a difference of Gaussian function (Y. J. Liu et al., 2011a) as follows:

$$
R_{s}=K_{e} \int_{-s}^{s} e^{\left(-x / r_{e}\right)^{2}} d x-K_{i} \int_{-s}^{s} e^{\left(-x / r_{i}\right)^{2}} d x+R_{0},
$$

in which $R_{s}$ is the response evoked by different aperture sizes. The free parameters, $K_{e}$ and $r_{e}$, describe the strength and the size of the excitatory space, respectively; $K_{i}$ and $R_{i}$ represent the strength and the size of the inhibitory space, respectively; and $R_{O}$ is the spontaneous activity of the cell.

The optimal spatial and temporal frequencies were extracted from the data fitted to Gaussian distributions using the following equation (DeAngelis et al., 1993; Van den Bergh et al., 2010):

$$
R_{S F / T F}=\text { baseline }+R_{\text {pref }} e^{-\frac{\left(S F / T F-S F / T F_{\text {pref }}\right)^{2}}{2 \sigma^{2}}}
$$

Where $R_{S F / T F}$ is the estimated response, $R_{\text {pref }}$ indicates response at preferred spatial or temporal frequency, $S F / T F$ indicates spatial or temporal frequency, $\sigma$ is the SD of the Gaussian, and baseline is Gaussian offset.

The contrast tuning was fitted by using the Naka-Rushton equation (Naka and Rushton, 1966; Albrecht and Hamilton, 1982; Van den Bergh et al., 2010; Przybyszewski et al., 2014):

$$
R(C)=\frac{g^{C^{n}}}{C_{50}^{n}+C^{n}},
$$

where $g$ is the gain (response), $C_{50}$ is a contrast at mid response, and $n$ is the exponent. For each fit, the background spontaneous activity was subtracted from the response curve and values below background SD were changed to 0 (Van den Bergh et al., 2010). The contrast threshold was defined as the contrast value exceeding $10 \%$ of maximum response.

The cumulative distribution function (CDF) was used to show and compare data distributions between animal groups. The CDF indicates the probability that the sample value will be less than or equal to the given parameter.

Experimental design and statistical analysis. All statistical comparisons were done for single-cell populations in three rat groups: normal, treated, and degenerated. The number of cells $(n)$ for each comparison is given in the corresponding figures under the bar graph panels. For each tested parameter, data distributions are represented in two ways: histograms and CDFs. For all tests, results were considered statistically significant at $p<0.05$. The $\chi^{2}$ test was used to evaluate the "presence-absence" of visual responses between animal groups. The Kolmogorov-Smirnov test was used for comparisons of distributions and CDFs. A two-tailed Man$\mathrm{n}-$ Whitney $U$ test was used for average differences between groups. Mean values given in Results include the SD, and histograms include error bars for the SEM. All offline data analysis and statistics were performed in MATLAB.

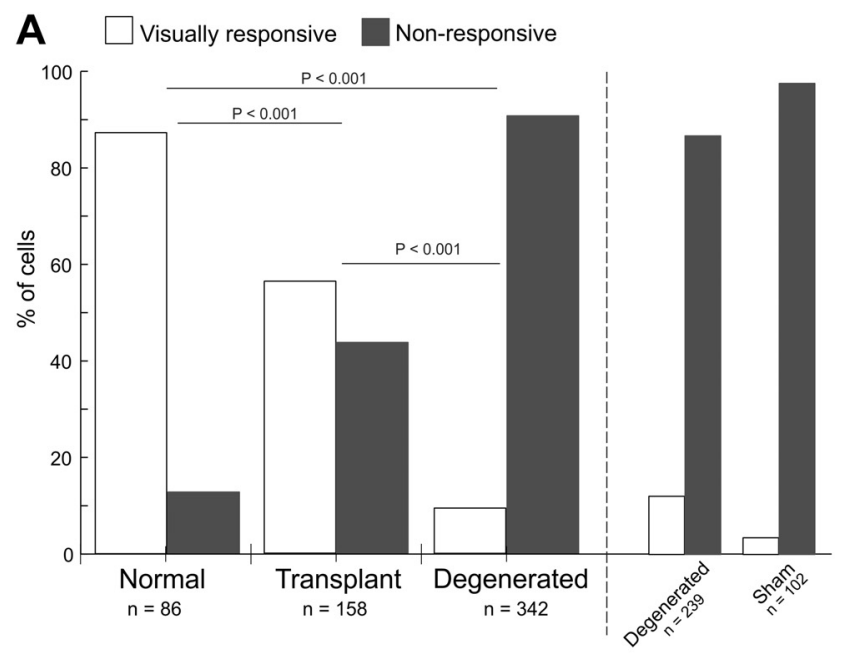

B
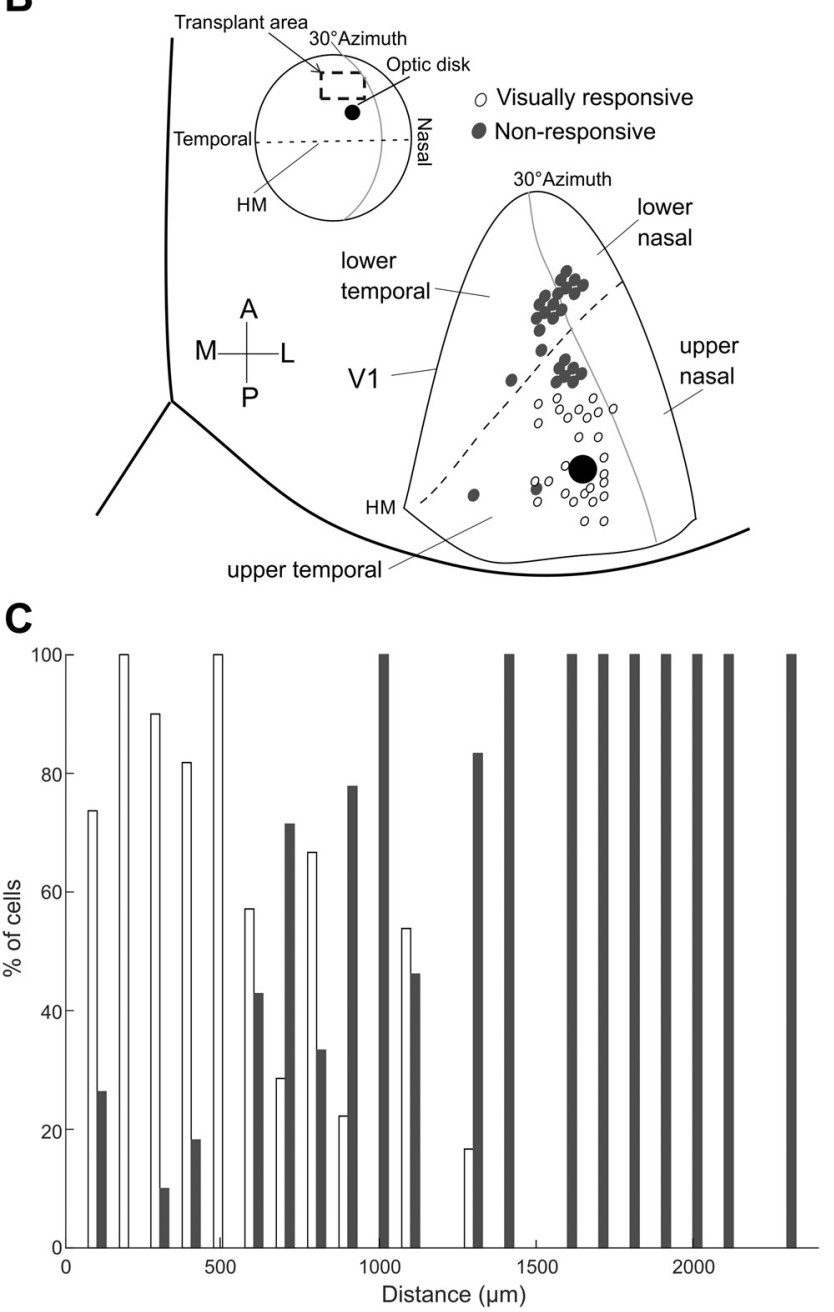

Figure 4. Summary of single-unit recordings in V1. $A$, Percentage of visually responsive cells in tested animal groups. Bars represent the percentage of visually responsive cells. $\boldsymbol{B}$, Drawing represents the position of $\mathrm{V} 1$ electrode tracks where visually responsive (open circles) or no visually responsive (filled circles) neurons were found relative to the optic disk representation of the transplanted eye in all cases. Top inset, Transplanted area relative to visual space and the location of the optic disk. C, For transplanted rats, the percentages of visually responsive and nonresponsive neurons are plotted over distance relative to the center of the transplant. 


\section{Results}

Retinal sheet transplant generates selective visual responses

To determine whether retinal sheet transplants can lead to visual responses at the cortical level, we recorded single neurons in V1 of four animal groups: healthy normal rats (Long-Evans, $n=4$; or NIH, $n=$ $4)$; line-3 rats with retinal sheet transplants $(n=6)$; line- 3 rats without transplants, which we label as degenerated $(n=$ 6); and line-3 rats with sham transplants $(n=2)$, which we group with degenerated for most analyses $(n=8)$. All included line-3-transplanted rats were considered to have healthy transplants; unhealthy transplanted rats were excluded from the study (see Materials and Methods). Examples from two line-3 rats with healthy transplants imaged in vivo are shown in Figure $2 A-E$. Transplants were subsequently verified through histology as being well integrated into the host retina (Fig. 2C,F) and to have produced new photoreceptors and rod bipolar cells as shown in Figure 3.

In animals with healthy transplants, we recorded from $158 \mathrm{~V} 1$ neurons in total. Of these, more than half $(56 \% ; n=89)$ were visually responsive (Fig. 4), significantly higher than the occurrence of visually responsive neurons in degenerated rats $(p<0.001$; Fig. $4 A)$. Of the 342 recorded neurons in degenerated rats without transplants, 91\% did not respond to light, $88 \%$ in degenerated rats without sham surgery $(n=211$ of 240$)$, and $97 \%$ in rats with sham surgery $(n=99$ of 102) (Fig. $4 A$ ). The data include recordings from 4 degenerated rats aged p26-35, around the same age transplants were made in other rats, in which $97 \%$ of tested neurons were not light-sensitive. This latter evidence supports anatomical results showing that rods are lost and cones significantly damaged by this age (Hombrebueno et al., 2010; Martinez-Navarrete et al., 2011; Zhu et al., 2013; LaVail et al., 2018). In addition, for the 32 responsive degenerated rat neurons, selectivity to visual features tested was poor (see below).

The occurrence of visually responsive neurons in transplanted rats was lower than normal rats, $87 \%$ (75 of 86 cells; $p<$ 0.001 ; Fig. $4 A$ ), but, nevertheless, represents a marked improvement over the degenerated and sham rats. In addition, the percentage of responsive neurons directly related to the transplant is even higher as most nonresponsive cells were found in recording tracks located further from the retinotopic location of the transplant, where visual input would need to be re-
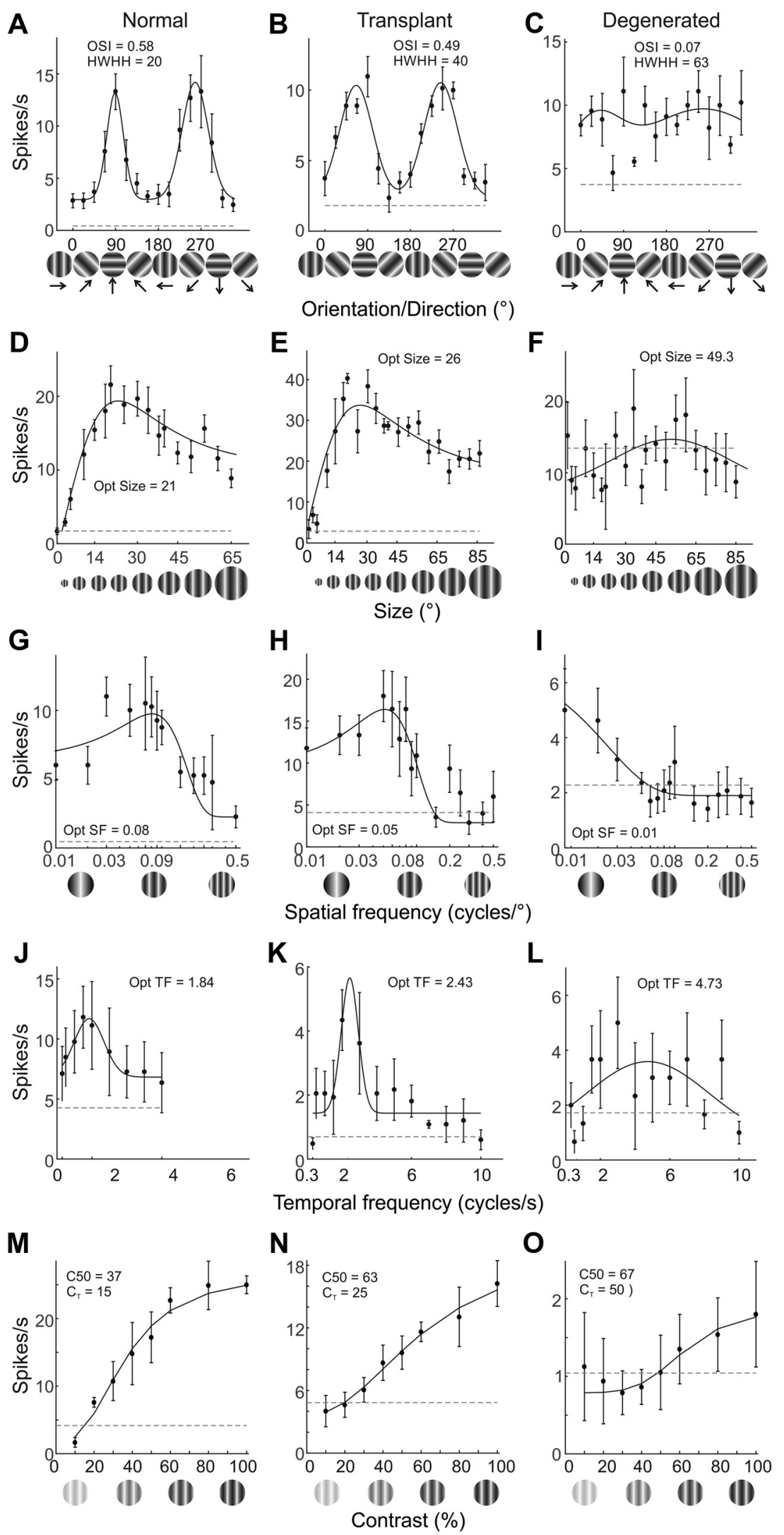

Figure 5. Example V1 neuron tuning curves in response to an array of visual stimuli. Left column, Cells from normal rats. Middle column, Transplanted rat cells. Right column, Cells from degenerated rats. Response profiles to drifting sign wave gratings presented at different orientations $(\boldsymbol{A}-\boldsymbol{C})$. OSI and HWHH values are included to facilitate comparisons. Response profiles are also shown for stimulus size $(\boldsymbol{D}-\boldsymbol{F})$, spatial frequency $(\boldsymbol{G}-\boldsymbol{I})$, temporal frequency $(\boldsymbol{J}-\boldsymbol{L})$, and contrast $(\boldsymbol{M}-\mathbf{0})$. Horizontal dashed lines indicate average spontaneous activity. 

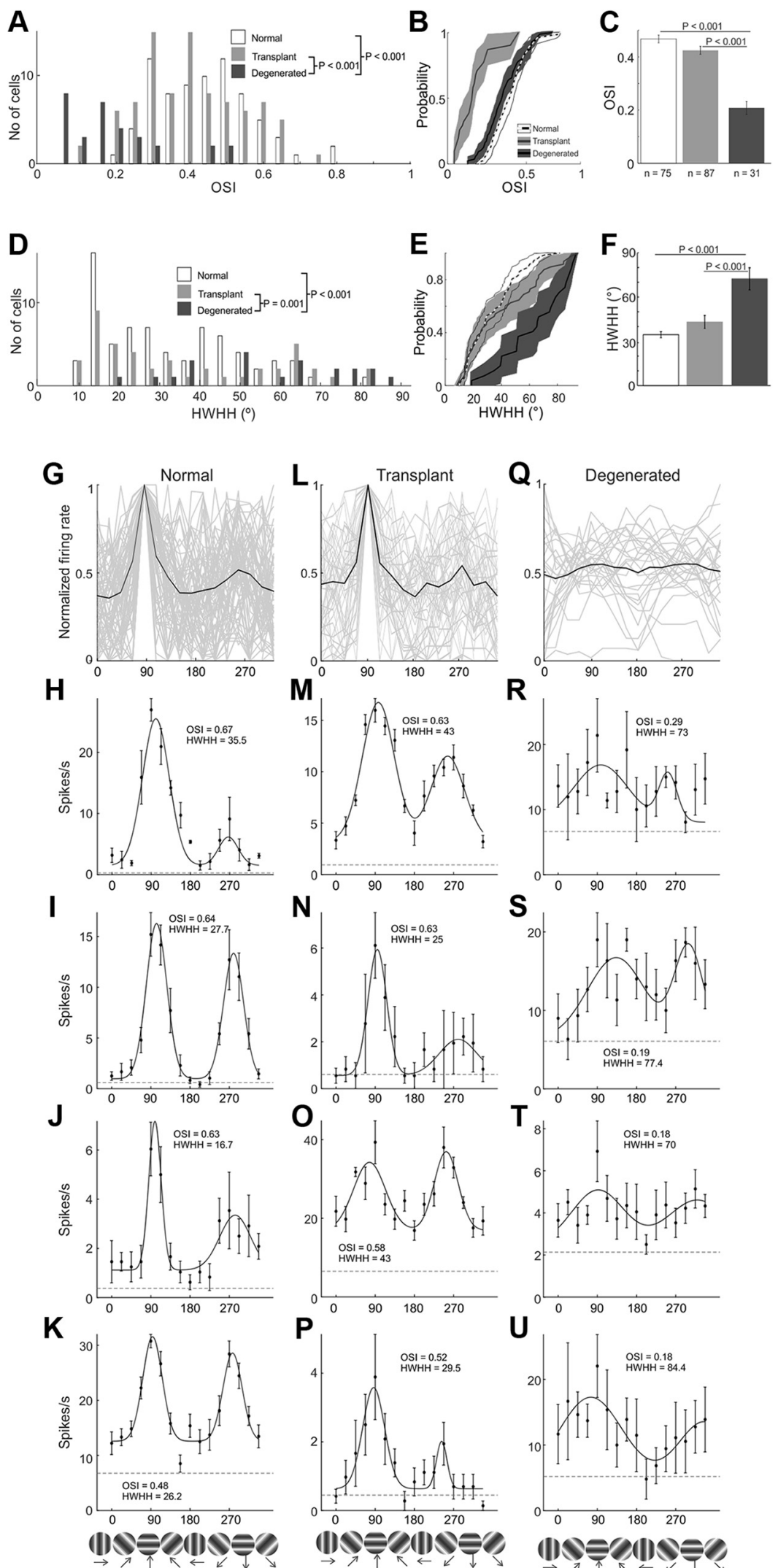

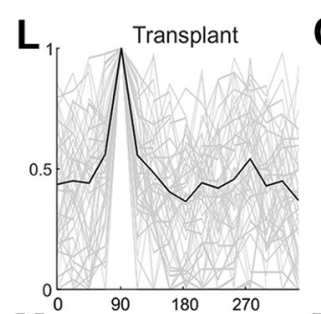

$\mathbf{M}^{0}$
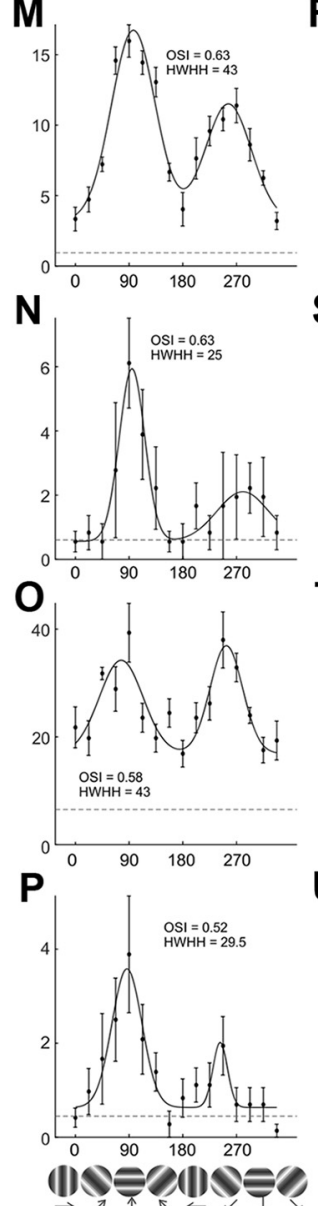

Orientation/Direction $\left({ }^{\circ}\right)$

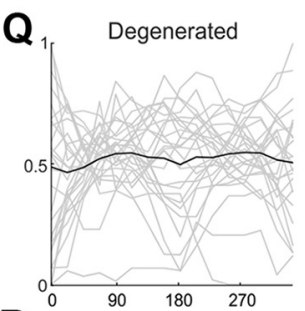

$\mathbf{R}$

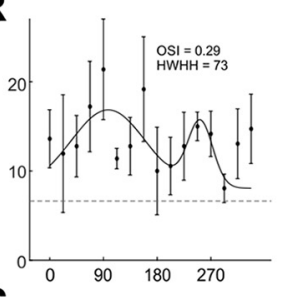

$\mathbf{S}$
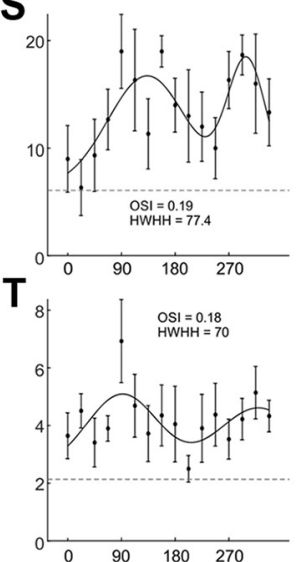

$\mathbf{U}$

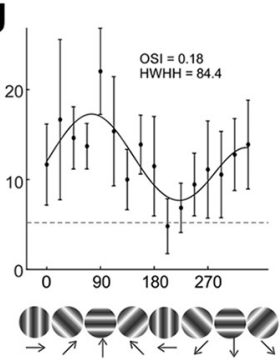

Figure 6. Population comparisons of orientation response for normal, transplanted, and degenerated rats. The distribution $(\boldsymbol{A}, \boldsymbol{D}), \operatorname{CDF}(\boldsymbol{B}, \boldsymbol{E})$, and average $(\boldsymbol{C}, \boldsymbol{F}) \operatorname{OSI}(\boldsymbol{A}-\boldsymbol{C})$ and HWHH $(\boldsymbol{D}-\boldsymbol{F})$ of 1 neurons are plotted for three different rat groups. Population orientation tuning curves for all cells are shown for normal $(\boldsymbol{G})$, transplant $(\boldsymbol{L})$, and degenerated $(\boldsymbol{Q})$ rats. Additional example orientation tuning curves for V1 cells from normal $(\boldsymbol{H}-\boldsymbol{K})$, transplanted $(\boldsymbol{M}-\boldsymbol{P})$, and degenerated rats $(\boldsymbol{R}-\boldsymbol{U})$. $p$ values are given where significant differences between groups were found. $\boldsymbol{A}, \boldsymbol{D}, \boldsymbol{p}$ values apply to $\boldsymbol{B}$ and $\boldsymbol{E}$ as well.

layed by the degenerated host retina (Fig. $4 B, C)$.

Every neuron responsive to drifting gratings in each animal group was tested for selectivity to five visual parameters: orientation and direction, size, spatial and temporal frequencies, and contrast. Representative tuning profiles for each parameter from example neurons are shown in Figure 5 for normal (left column), transplant (center column), and degenerated (right column) rats. From this point, the three visually responsive cells from degenerated rats with sham surgery are combined with the degenerated cells for analysis. Several more example tuning curves are shown in Figures 6-10.

\section{Orientation and direction responses}

Orientation and direction selectivity are prominent characteristics of neurons in primary visual cortex and are key to the perception of form and motion in higher visual cortex (e.g. Hubel and Wiesel, 1962; Livingstone and Hubel, 1988; Glickfeld et al., 2013; Glickfeld and Olsen, 2017). Generation of orientation-selective responses in degenerated rats through retinal sheet transplant would therefore represent a major advance toward achieving quality vision. Success in this regard can be seen in the orientation tuning profile of the transplanted rat neuron in Fig. $5 B$, which shows a sharply tuned orientation response (OSI $=0.49)$, compared with the highly variable and low-amplitude response of the example-degenerated cell $(\mathrm{OSI}=0.07$; Fig. $5 C)$. The selectivity of the transplant cell more resembles the normal rat neuron in Figure $5 A$, which had an OSI of 0.58 .

The population distribution (Fig. $6 A$ ) and additional examples also show that several normal and transplant cells have OSIs $>0.60$ (Fig. $6 H-J, M, N$ ). These examples include multiple cells with clear direction selectivity (Fig. $6 H, J, N, P$ ). Conversely, degenerated OSIs were nearly all $<0.30$ (Fig. $6 A, R-U$ ). Comparing population averages, transplanted cell selectivity was significantly higher than degenerated rat cells at more than twice the OSI $(0.43 \pm 0.14$ compared with $0.21 \pm$ $0.14, p<0.001$; Fig. $6 C$ ). In addition, as noted above, only $9 \%$ of degenerated rat neurons responded at all, compared with $56 \%$ in transplanted rats (Fig. $4 A$ ). Remarkably, the average OSI in transplanted rats was near that of normal rats, at $0.47 \pm$ 0.13 , and not statistically different $(p=$ 0.07 ; see Fig. $11 A$ ). This can also be seen in the high degree of overlap for the CDFs (Fig. 6B) and in the similarity of their pop- 
ulation tuning curves (Fig. 6G,L). Similarly, tuning widths measured as the $\mathrm{HWHH}$ were comparable between normal $(35 \pm 17)$ and transplant $(43 \pm 31)$ rats and significantly narrower than for degenerated rats $(72 \pm 39 ; p<0.001$; Fig. $6 D-F)$.

\section{Size tuning}

Size tuning is another visual feature that does not fully emerge until cortex (Cavanaugh et al., 2002; Sceniak et al., 2006; Alitto and Usrey, 2008; Y. J. Liu et al., 2011a, 2015; Hashemi-Nezhad and Lyon, 2012) and also plays an important role in shape perception where a smaller preferred size can provide more stimulus detail to higher-order visual areas (Kobatake and Tanaka, 1994; Glickfeld et al., 2014). Tuning profiles from representative example neurons are shown across the second row in Figure 5. Peak responses correspond to the optimal stimulus size for each neuron, the size that elicits the maximum response. Optimal size for the example from a normal rat was $21^{\circ}$ (Fig. $5 D$ ), and is similar to the example from a transplanted rat neuron $\left(26^{\circ}\right.$; Fig. $\left.5 E\right)$. On the other hand, the cell from a degenerated rat had a larger optimal size $\left(49^{\circ}\right)$ and showed a more variable response with only a handful above the relatively high spontaneous firing rate (Fig. $5 F$ ). Additional examples showed the same pattern, smaller optimal sizes for normal (Fig. $7 E-H$ ) and transplanted neurons (Fig. 7J$M)$, compared with large sizes and highly variable responses in degenerated rats (Fig. 7O-R).

In the population, normal cells showed optimal sizes as small as $3^{\circ}$ and as large as $42^{\circ}$ (Fig. $7 A$ ), with an average of $21^{\circ} \pm 10^{\circ}$ (Fig. 7C), on par with published data from sighted rats (Girman et al., 1999). Transplant rat neurons showed a relatively similar optimal size distribution ranging from $7^{\circ}$ to $60^{\circ}$ (Fig. $7 A$ ) and similar optimal sizes in population tuning curves (Fig. $7 D, I)$. Although larger than the normal population $\left(18^{\circ} \pm 8^{\circ}\right)$, the transplant average size $\left(24^{\circ} \pm 6^{\circ}\right)$ was not statistically different $(p>0.1)$ and was a major and highly significant improvement over degenerated rats, which had nearly twice the preferred size $\left(43 \pm 15^{\circ} ; p=0.001\right.$; Fig. $7 A-C)$.

\section{Spatial frequency preference}

Similar to preference for smaller stimulus size, V1 neurons responding better to higher spatial frequencies are essential for visual acuity and detailed form vision. In keeping with improvements seen in orientation selectivity and size tuning, the average preferred spatial frequency in transplanted rats was three times
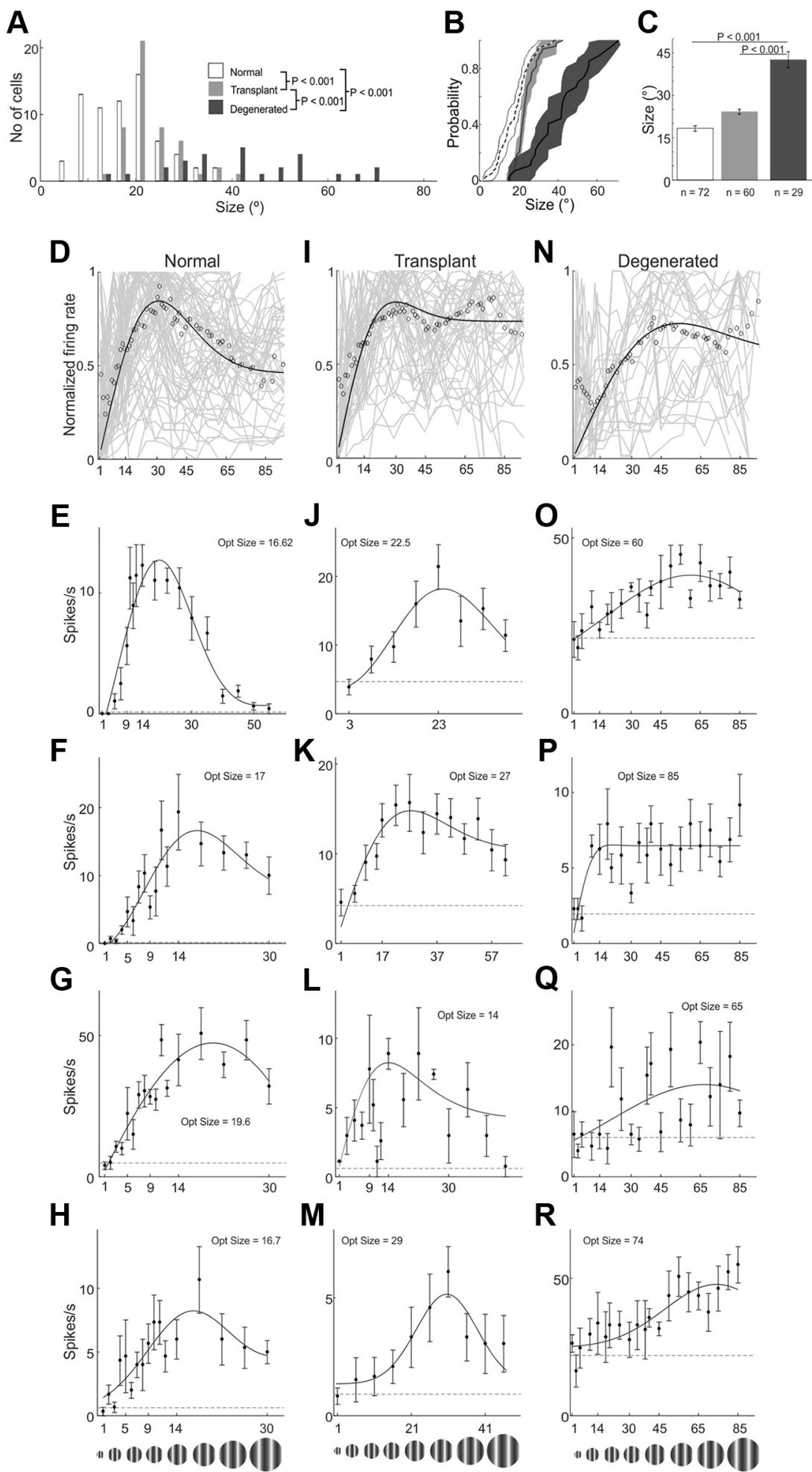

M
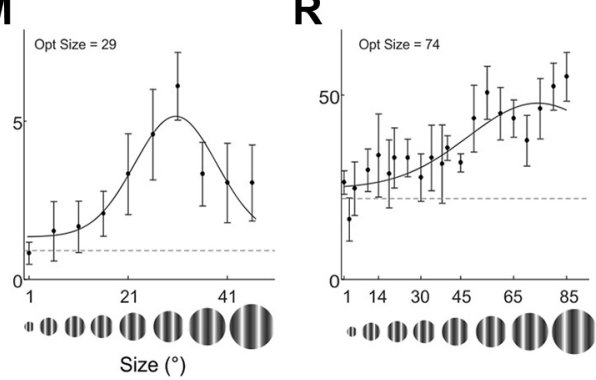

Figure 7. Population comparisons of size tuning for normal, transplanted, and degenerated rats. The distribution $(\boldsymbol{A}), \operatorname{CDF}(\boldsymbol{B})$, and average $(\boldsymbol{C})$ optimal size for $V 1$ neurons are plotted for three different rat groups. Population size tuning curves for all cells are shown for normal $(\boldsymbol{D})$, transplant $(\boldsymbol{I})$, and degenerated $(\boldsymbol{N})$ rats. Additional example size tuning curves for $V 1$ cells from normal $(\boldsymbol{E}-\boldsymbol{H})$, transplanted $(\boldsymbol{J}-\boldsymbol{M})$, and degenerated rats $(\boldsymbol{O}-\boldsymbol{R})$. Conventions are as described in Figure 6. higher $\left(0.06 \pm 0.03\right.$ cycles $\left.^{\circ}\right)$ than degenerated rats $(0.02 \pm 0.02$ cycles $\left./{ }^{\circ} ; p=0.001\right)$; and, although lower than normal rats $(0.10 \pm 0.10$; Fig. $8 C)$, it was not statistically different $(p=0.4)$. The lower spatial frequency preferences of degenerated rat neurons is shown in the population distribution (Fig. 8A,B) and 

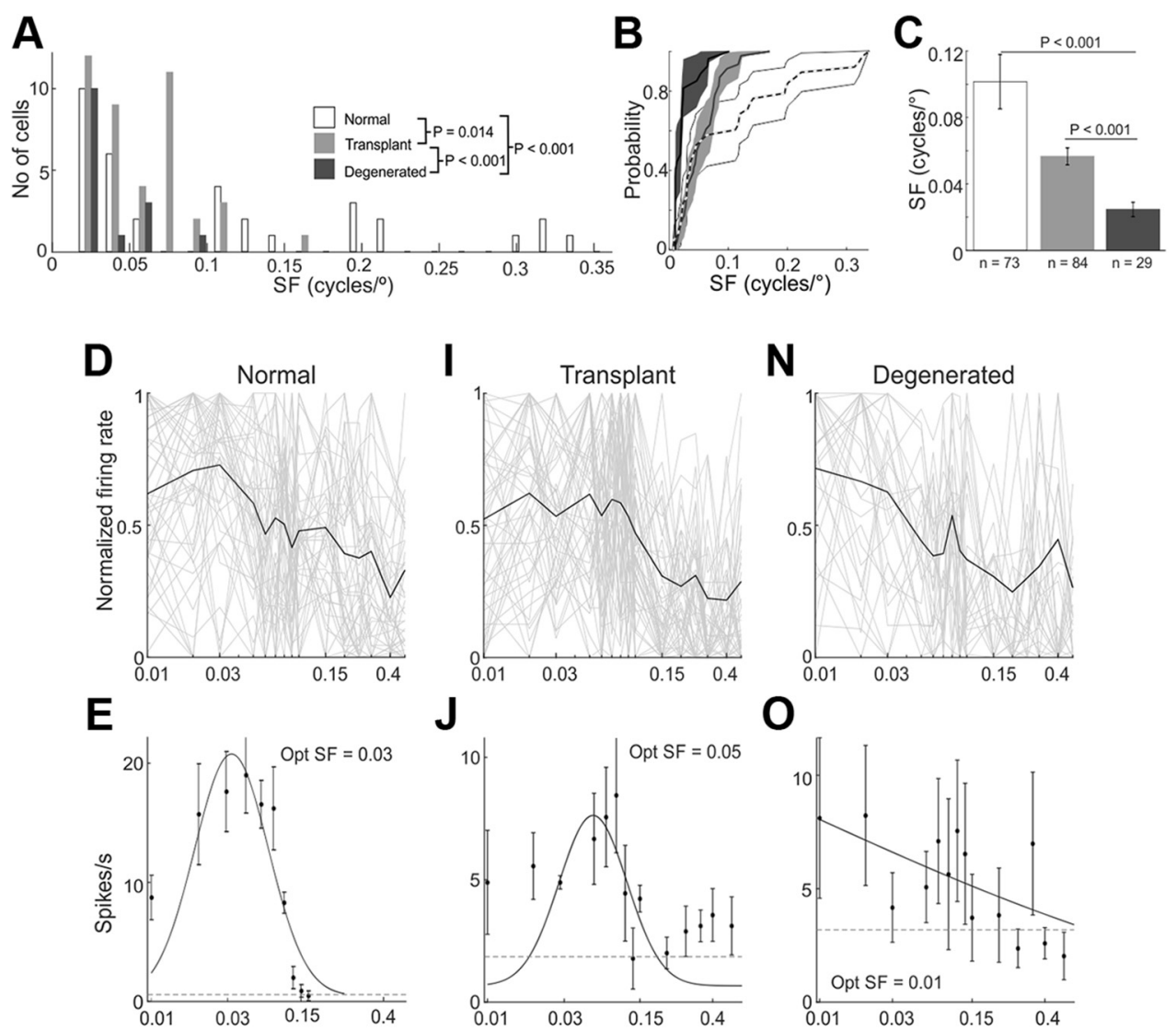

\section{0}
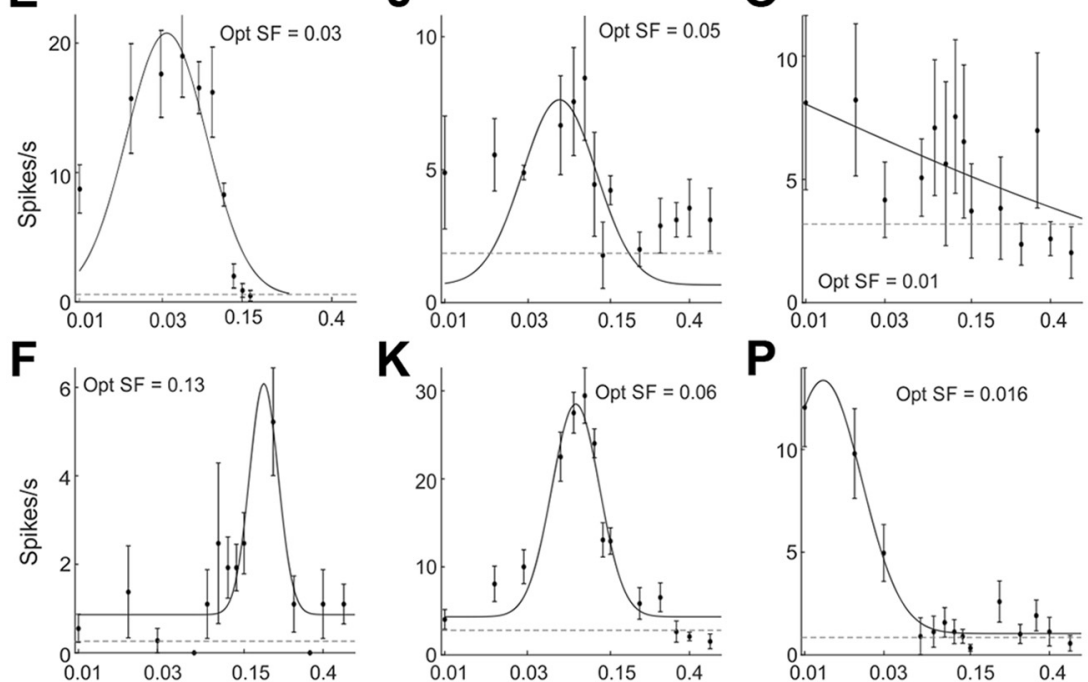

K

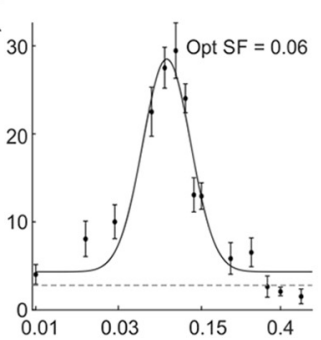

P
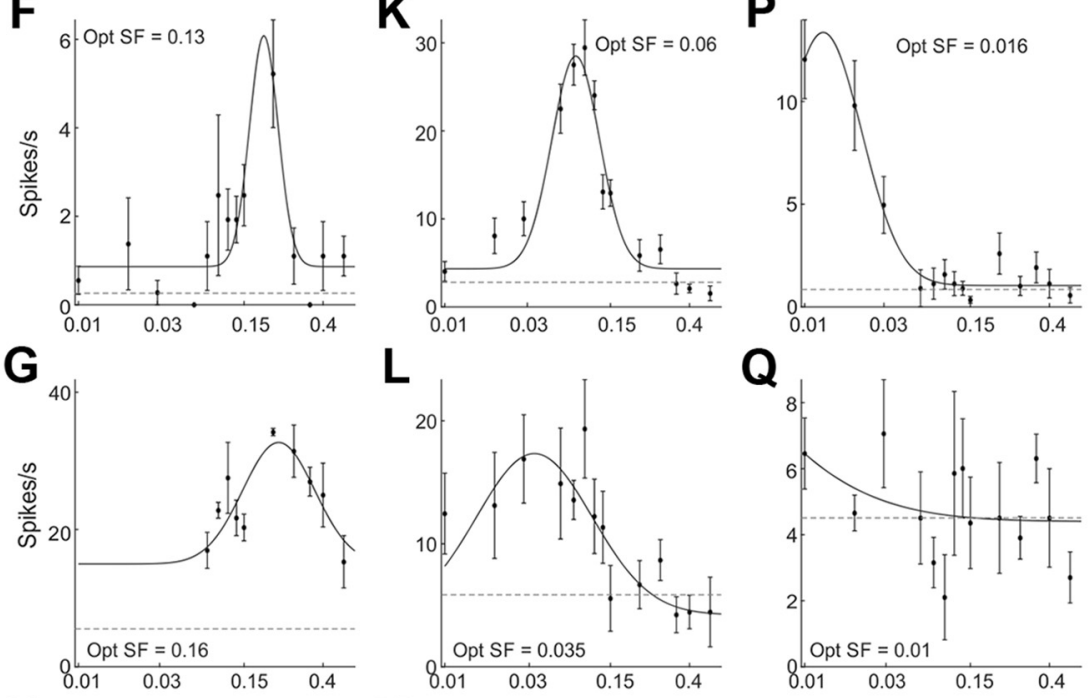

L
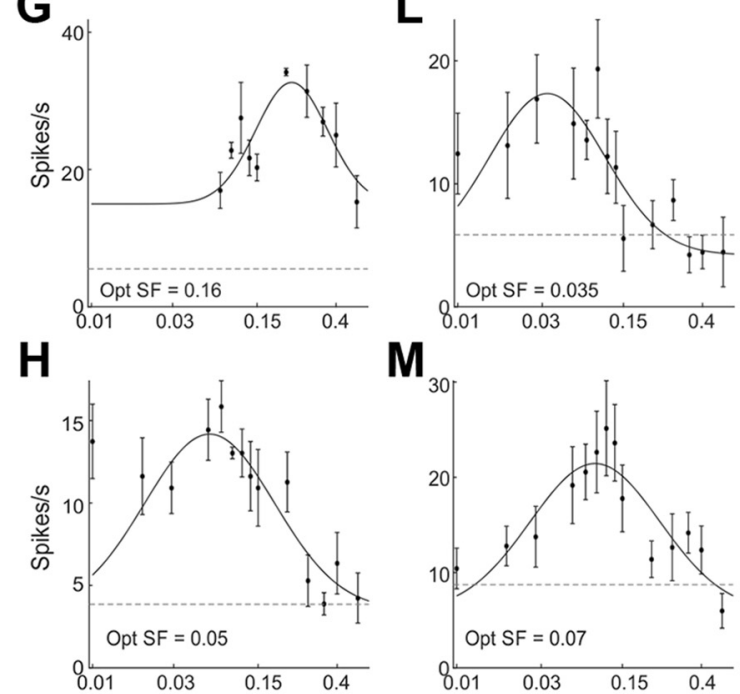

M

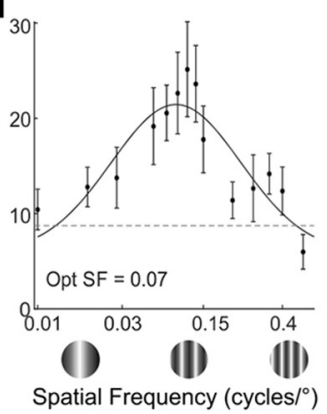

$\mathbf{Q}$

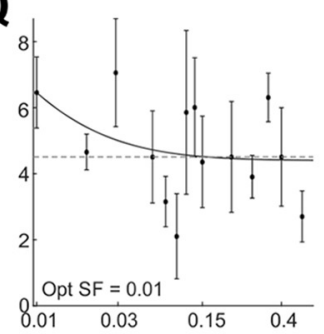

R

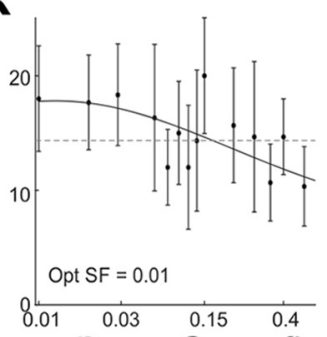

(I) (I) (II)

Figure 8. Population comparisons of preferred spatial frequency for normal, transplanted, and degenerated rats. The distribution (A), $C D F(B)$, and average $(\boldsymbol{C})$ preferred spatial frequencies for V1 neurons are plotted for three different rat groups. Population spatial frequency tuning curves for all cells are shown for normal (D), transplant (I), and degenerated ( $\boldsymbol{N}$ ) rats. Additional example spatial frequency tuning curves for $\mathrm{V} 1$ cells from normal $(\boldsymbol{E}-\boldsymbol{H})$, transplanted $(\boldsymbol{J}-\boldsymbol{M})$, and degenerated rats $(\boldsymbol{O}-\boldsymbol{R})$. Conventions are as described in Figure 6. 
reflected in the population tuning curves (Fig. $5 \mathrm{~N}$ ) and additional examples (Fig. $80-R$ ). In each example, the neurons responded better to spatial frequencies at $\leq 0.03$ cycles $^{\circ}$, with one responding optimally to $>0.05$ cycles ${ }^{\circ}$. In contrast, the majority of transplant (Fig. $8 I-M$ ) and normal (Fig. $8 E-H$ ) rat neurons responded optimally to frequencies $>0.03 \mathrm{cy}-$ cles ${ }^{\circ}$, with several at or $>0.05$ cycles ${ }^{\circ}$ (Figs. $5 G, H$, Fig. $8 A$ ).

\section{Temporal frequency preference}

A wide range of temporal frequency preferences were observed for $\mathrm{V} 1$ neurons in all rat groups (Fig. 9A). On average, degenerated $(3.1 \pm 1.8$ cycles $/ \mathrm{s} ; p=0.003)$ and transplant $(2.6 \pm 1.9$ cycles $/ \mathrm{s} ; p=$ $0.006)$ rats both had higher preferences than normal $(2.0 \pm 2.4$ cycles $/ \mathrm{s})$ rats, each difference being statistically significant (Fig. 9A-C). Because, especially in degenerated rats, responses were highly variable (Fig. $9 N-R$ ), it is unclear whether the higher temporal frequency preferences may be due to other factors. Regardless, our data show that retinal sheet transplants brought temporal frequency preference closer to normal rat V1 neurons.

\section{Contrast response}

Contrast response profiles showed that V1 neurons in transplanted rats had a somewhat lower contrast threshold than degenerated rats (compare Fig. $5 \mathrm{~N}$ with Fig. $5 O$ and Fig. $10 I-M$ with Fig. $10 N-R$ ). Using $50 \%$ of maximum response (C50) to make comparisons, average C50 for transplant rat neurons (52 $\pm 28 \%$ ) was significantly lower than degenerated rat $(65 \pm 21 \%$; $p=0.003)$. This was also reflected in the population distribution, $\mathrm{CDF}$, and population tuning curves (Fig. $10 A, B, D, I, N)$. The average C50 for normal rats was $37 \pm 22 \%$, significantly lower than transplanted and degenerated rats $(p<0.001)$. Of note, compared with other rats, most normal rat neurons saturated at $\sim 60 \%-80 \%$ contrast, as is common (Figs. 5M, Fig. 10 F, G). Nevertheless, some neurons in transplant (Fig. $10 \mathrm{~J}, \mathrm{~K}$ ) and degenerated (Fig. 10O,P) rats did also show contrast saturation.

\section{Response latency}

Latency of visually responsive neurons was analyzed as well. Previously, recordings in the superior colliculus in response to low luminance flashes found response latencies of transplanted rats to be delayed compared with normal, with responsive degenerated rat cells showing an even greater lag (Thomas et al., 2004; Seiler et al., 2010, 2017; Yang et al., 2010). Here we found a similar result in V1 as shown in three example neurons (Fig. 11A-F). Population average
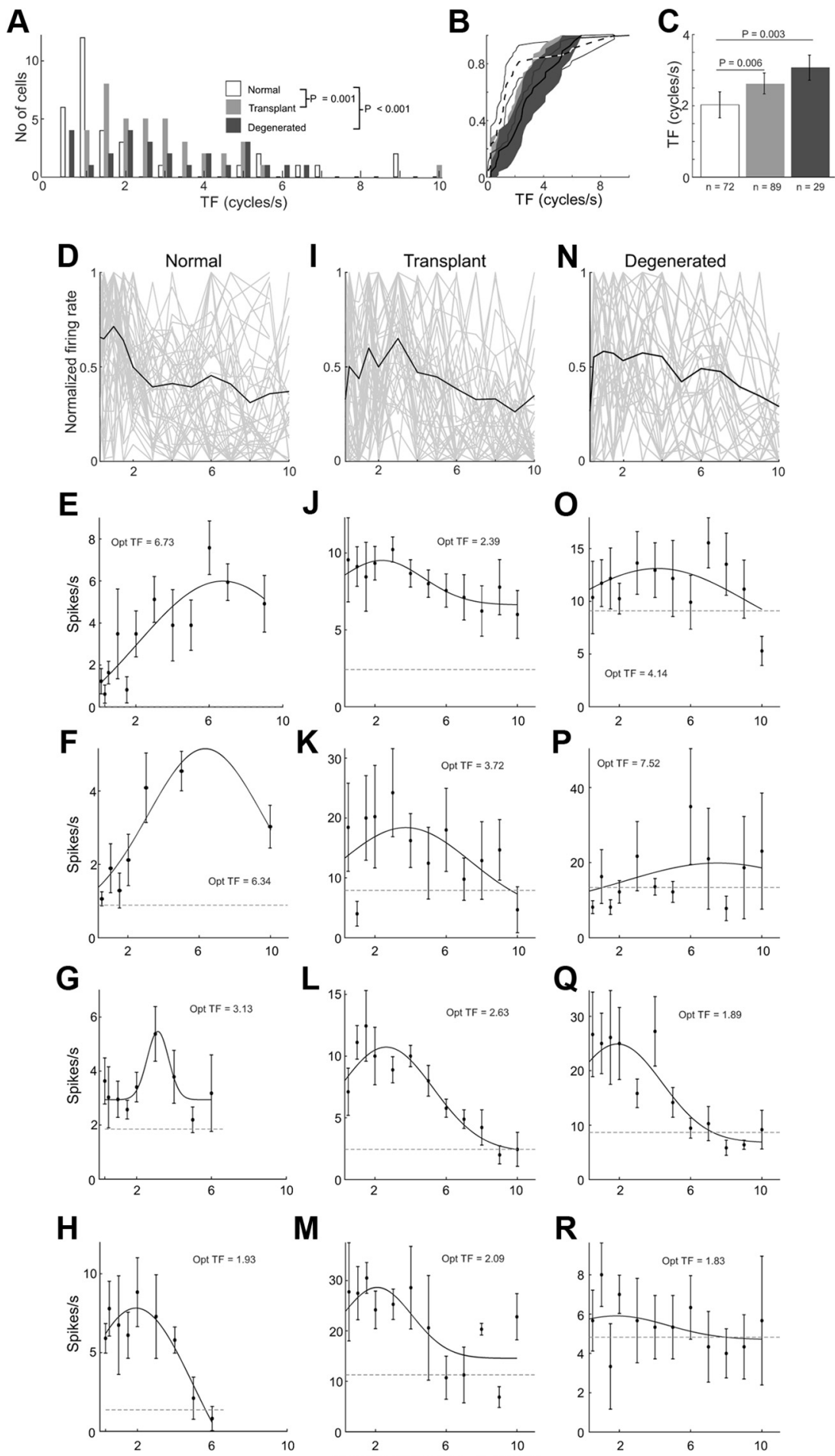

M

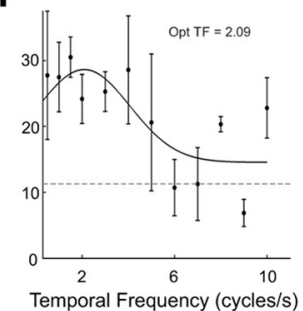

$\mathbf{R}$

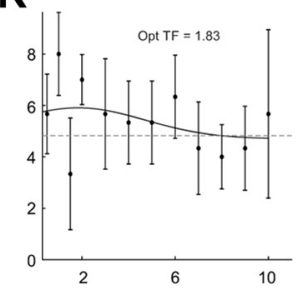

Figure 9. Population comparisons of preferred temporal frequency for normal, transplanted, and degenerated rats. The distribution $(\boldsymbol{A}), \mathrm{CDF}(\boldsymbol{B})$, and average $(\boldsymbol{C})$ preferred temporal frequencies for V1 neurons are plotted for three different rat groups. Population temporal frequency tuning curves for all cells are shown for normal $(\boldsymbol{D})$, transplant $(\boldsymbol{I})$, and degenerated $(\boldsymbol{N})$ rats. Additional example temporal frequency tuning curves for 11 cells from normal $(\boldsymbol{E}-\boldsymbol{H})$, transplanted $(\boldsymbol{J}-\boldsymbol{M})$, and degenerated rats $(\mathbf{O}-\boldsymbol{R})$. Conventions are as described in Figure 6.

response latencies were $77 \pm 25,119 \pm 20$, and $165 \pm 62 \mathrm{~ms}$ in normal, transplanted, and degenerated rats, respectively, with each difference being statistically significant $(p<0.01$; Fig. $11 J)$.

For each cell, response onsets were determined as the point where firing rate showed a $10 \%$ increase over the average spon- 

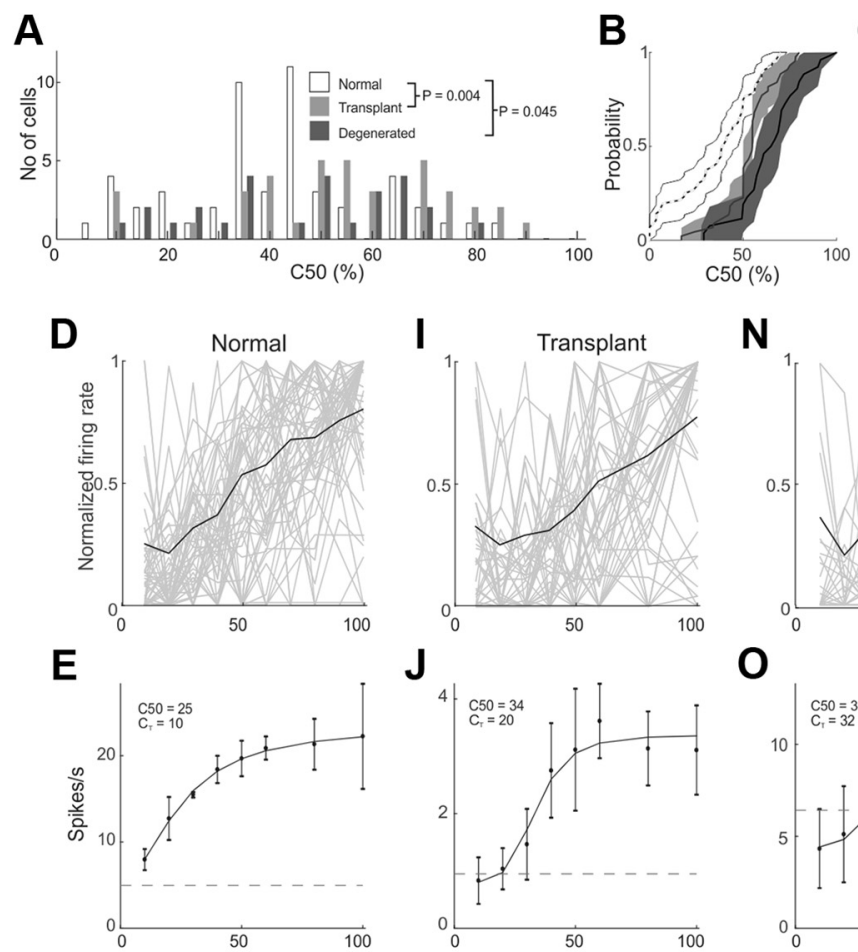

J
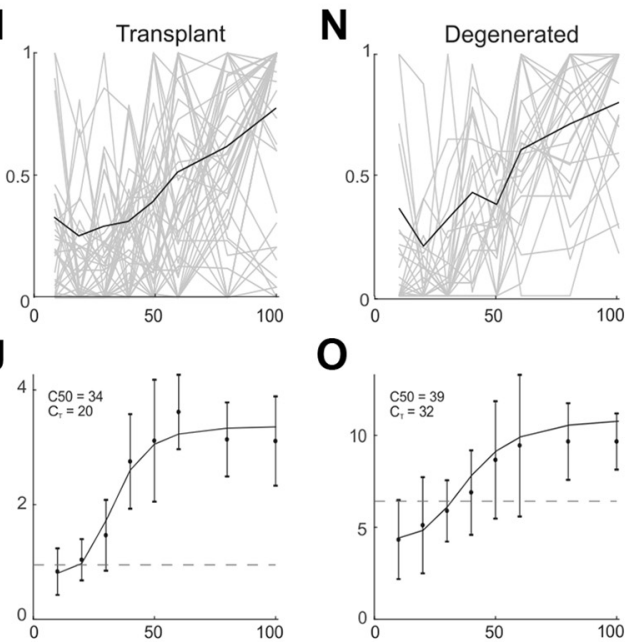

O
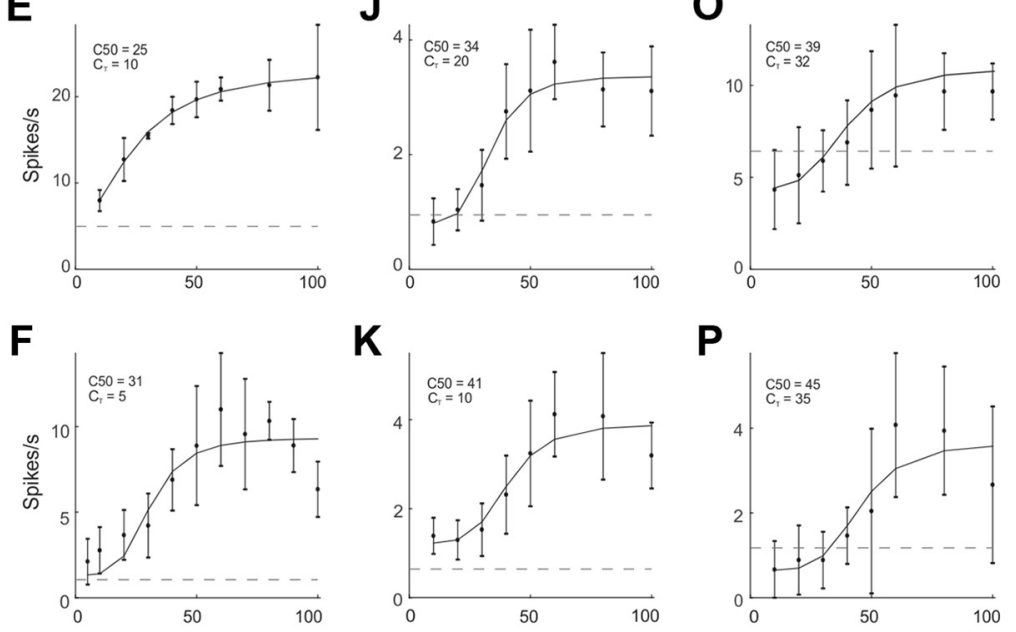

K

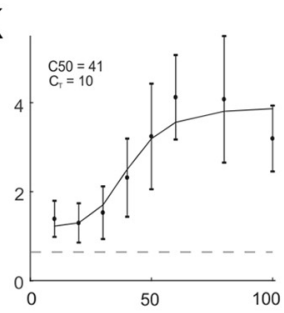

$\mathbf{P}$
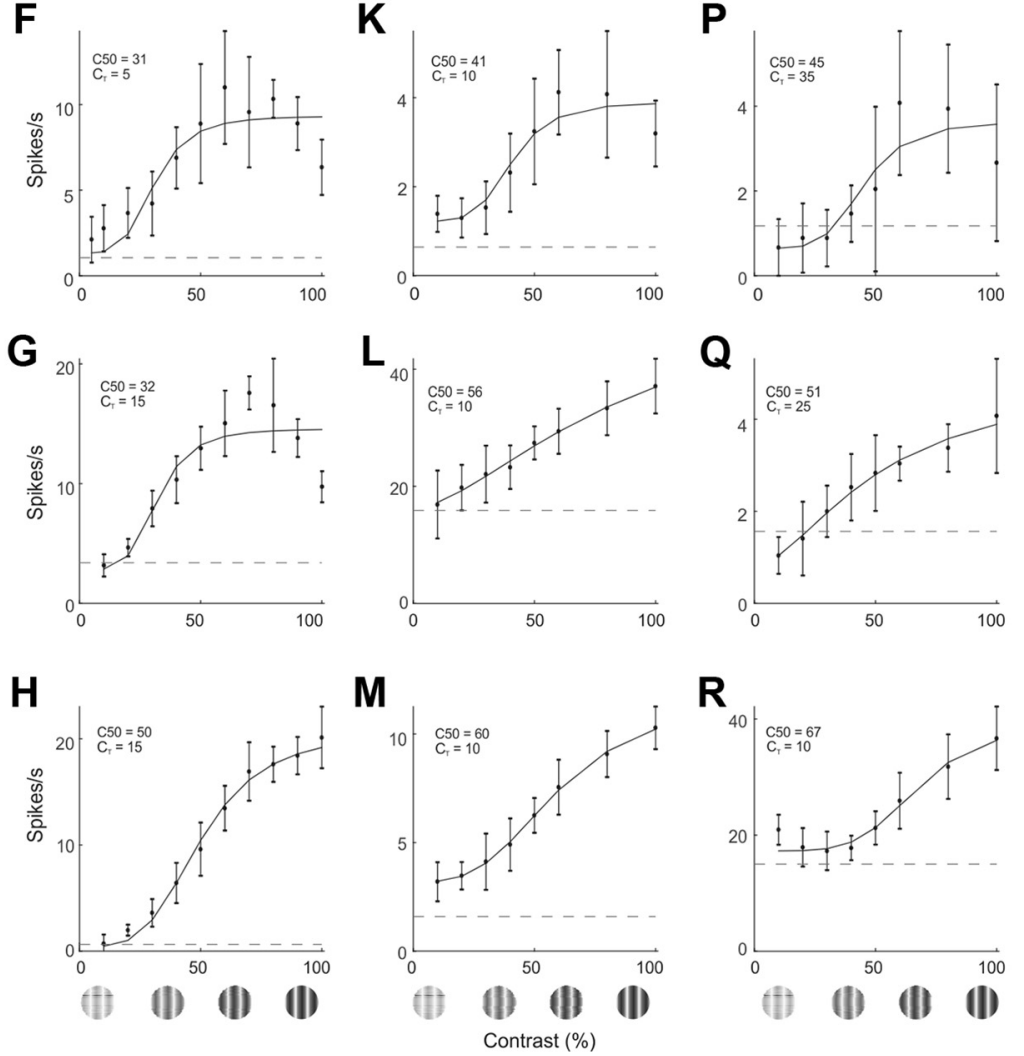

Figure 10. Population comparisons of contrast response for normal, transplanted, and degenerated rats. $\boldsymbol{A}$, The distribution $(\boldsymbol{A}), \mathrm{CDF}(\boldsymbol{B})$, and average $(\boldsymbol{C}) \mathrm{C50}$ for V1 neurons are plotted for three different rat groups. Population contrast response profiles for all cells are shown for normal $(\boldsymbol{D})$, transplant $(\boldsymbol{I})$, and degenerated $(\boldsymbol{N})$ rats. Additional contrast response profiles for $V 1$ cells from normal $(\boldsymbol{E}-\boldsymbol{H})$, transplanted $(\boldsymbol{J}-\boldsymbol{M})$, and degenerated rats $(\boldsymbol{O}-\boldsymbol{R})$. Conventions are as described in Figure 6.

taneous firing rate, which was determined as the average spike rate over the $500 \mathrm{~ms}$ before stimulus onset. This point is indicated in the average population response profiles over time by vertical dashed lines in Figure $11 G-I$. There was a more gradual increase

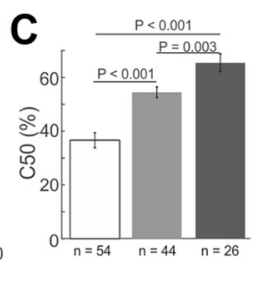

in response in degenerated rats (Fig. 11I), which was a likely result of many degenerated rat neurons having higher spontaneous firing rates. The average spontaneous firing rate for degenerated rats $(7.5 \pm 13.9$ spikes/s) was significantly higher than for transplant $(3.2 \pm 3.2$ spikes $/ \mathrm{s} ; p=0.001)$ and normal $(4.8 \pm 6.7$ spikes $/ \mathrm{s} ; p=0.025)$ rats $($ Fig. $11 \mathrm{~K})$. Although lower, the difference between transplanted and normal rats was not statistically significant $(p=$ 0.5 ). No statistical differences between rat groups were found for maximum firing rates (Fig. 11L).

Retinal sheet transplantation facilitates connectivity within rat visual system

To reveal changes in connectivity within the rat visual system, we injected a glycoprotein-deleted rabies virus (Wickersham et al., 2007a) expressing green or red fluorescent proteins to retrogradely trace connectivity within V1, from higher visual cortex to V1, and V1 inputs from the thalamus. The glycoprotein deletion in the rabies viral construct allows for selective labeling of input neurons, restricting the labeling across a single synapse to confirm only direct inputs (Wickersham et al., 2007b).

As for V1 recordings, animals used for retrograde tracing of $\mathrm{V} 1$ connections were divided into three groups: normal healthy rats $(n=4)$, transplanted line- 3 rats $(n=$ 5 ), and degenerated line-3 rats without transplant $(n=4)$. Transplant health was confirmed in vivo, as described above (Figs. 2, 3). Injections in transplanted rats were made in confirmed visually responsive regions of $\mathrm{V} 1$.

Examples of V1 injection sites in transplanted and degenerated rats are shown in Figure 12. The first notable result is that the degenerated rat had a distinct cluster of LGN-labeled neurons (Fig. 12F), demonstrating that feedforward input to V1 remains, even without a functioning retina. Comparing the two cases, the number of LGN neurons in the transplanted rat (Fig. 12C) was more than in the degenerated rat (Fig. $12 \mathrm{~F}$ ), suggesting a possible reduction in the level of LGN inputs to V1 without the transplantation treatment. To compare across cases, cell counts were normalized by dividing the number of cells found in the LGN by the number of locally infected V1 cells (Fig. 13A) and converted to a percentage (Fig. 13B), the number of locally infected neurons serving as a measure of the viral efficacy. The average percentage of LGN inputs for the population of degenerated rats $(1.8 \pm 2.8 \%)$ was lower than found for normal $(7.8 \pm 4.8 \%)$, and transplanted $(12.1 \pm$ $10.9 \%)$ rats, and statistically significant $(p<0.05$; Fig. 13B). For the 
A

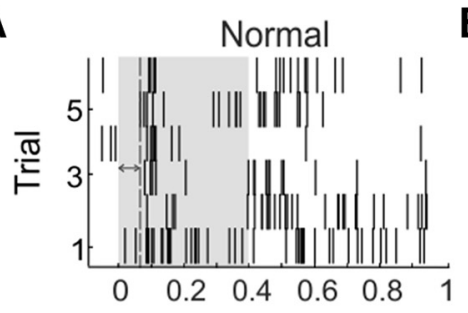

D

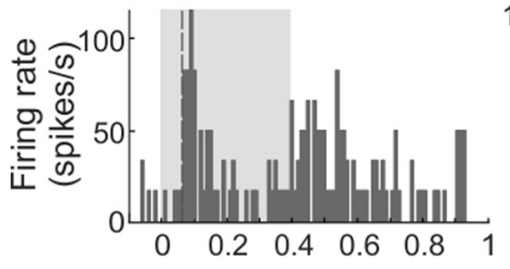

G

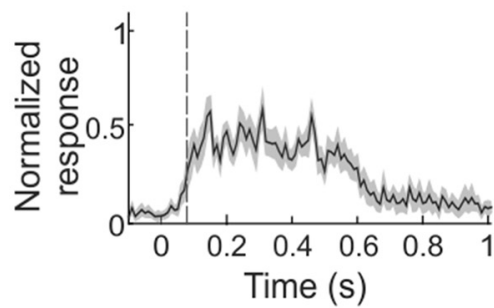

J

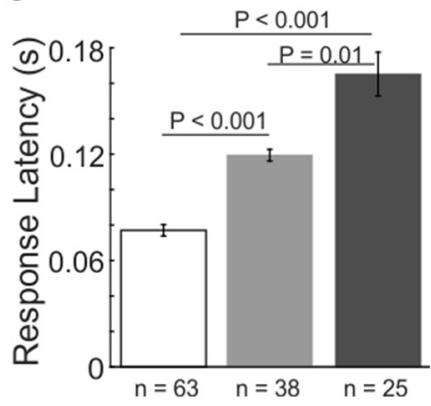

B

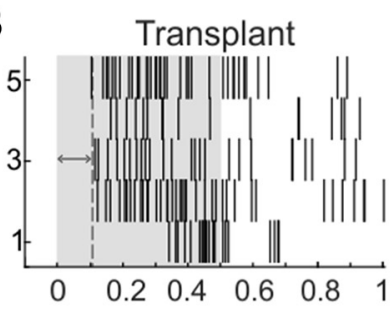

E

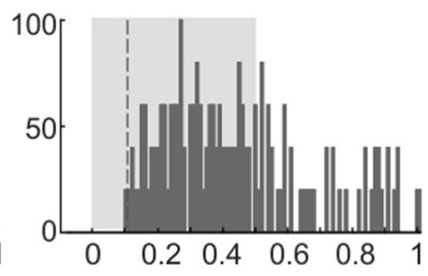

H

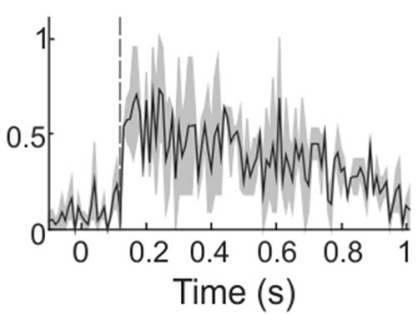

K

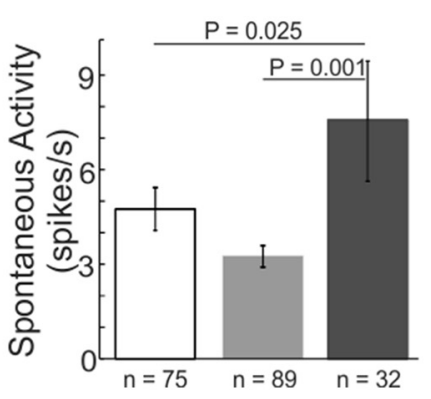

C

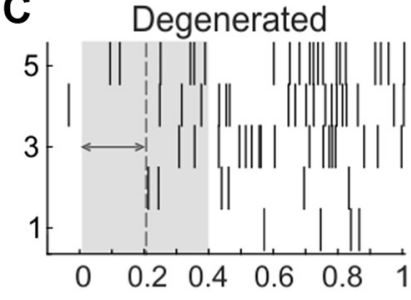

F

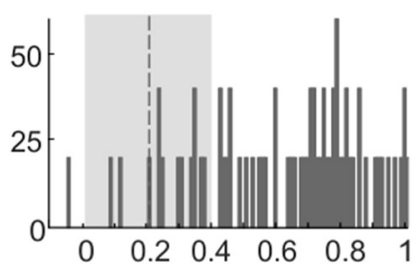

I

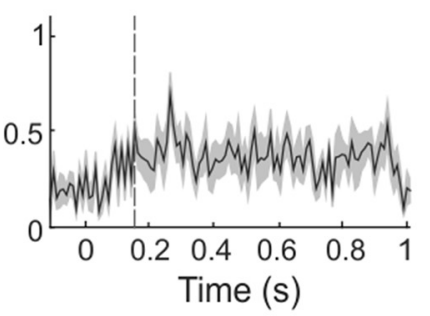

L

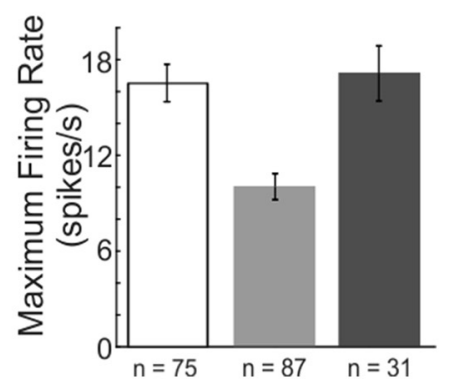

Figure 11. Response latency and spontaneous and maximum firing rates for normal, transplanted, and degenerated rat V1 neurons. Raster plots $(\boldsymbol{A}-\boldsymbol{C})$ and poststimulus time histograms $(\boldsymbol{D}-\boldsymbol{F})$ represent responses of example neurons from a normal $(\boldsymbol{A}, \boldsymbol{D})$, transplanted $(\boldsymbol{B}, \boldsymbol{E})$, and degenerated $(\boldsymbol{C}, \boldsymbol{F})$ rat. A full-screen bright stimulus was shown for $0.5 \mathrm{~s}$ beginning at Time 0 . Vertical dashed line indicates response onset, based on a $10 \%$ increase over the average spontaneous firing rate. Spontaneous firing rate was determined over the $0.5 \mathrm{~s}$ before stimulus onset. Population responses over time are shown for normal $(\boldsymbol{G})$, transplant $(\boldsymbol{H})$, and degenerated $(\boldsymbol{I})$ rats. Average response latency $(\boldsymbol{J})$, spontaneous activity $(\boldsymbol{K})$, and maximum firing rate $(\boldsymbol{L})$ are shown for the $\mathbf{V} 1$ population of the three rat groups. Conventions are as described in Figure 6.

adjacent LP nucleus, the percentages of inputs to V1 in normal $(1.4 \pm 1.6 \%)$, transplanted $(1.1 \pm 1.4 \%)$, and degenerated $(0.7 \pm$ $10.6 \%)$ groups were not statistically different ( $p>0.4$; Fig. 13B).

Within visual cortex, V1 injections in a transplanted (Fig. $12 B$ ) and degenerated (Fig. 12E) rat both showed dense clusters of infected neurons locally, within $300 \mu \mathrm{m}$ of the injection center. By contrast, long-range connections within V1, beyond $300 \mu \mathrm{m}$, were substantially reduced in the degenerated rat. For the population, $\sim 400$ local neurons were found on average in all three rat groups (Fig. 13A), indicating a similar degree of local connectivity. Relative to local connectivity, long-range V1 connections were significantly lower for degenerated rats $(22 \pm 12 \%$; $p=0.01)$ compared with normal $(55 \pm 10 \%)$ and transplanted (74 \pm 26; Fig. 13B) groups.

\section{Discussion}

In this study, we show that retinal sheet transplants can lead to nearly normal quality visual responses at the cortical level in an- imal models with severe retinal degeneration. Transplants not only helped to improve sight well beyond the capabilities of nontransplanted animals but also preserved underlying neural connectivity. This method shows promise for treating advanced stages of retinal diseases, such as macular degeneration and retinitis pigmentosa, where most photoreceptors are gone, and for which no treatments currently exist.

The fetal retinal sheet transplant is a well-organized structure of fetal progenitor cells, which differentiate into fully functional photoreceptors that integrate with bipolar and amacrine cells of the host retina. The reliability of retinal sheet transplants in the manner used here has been verified now in several previous animal studies (Seiler and Aramant, 1998; Aramant and Seiler, 2002; Seiler et al., 2005, 2017; Yang et al., 2010; Martinez-Navarrete et al., 2011) and even in humans (Radtke et al., 2008). In this study, we verified that transplants were well integrated into the host retina and produced new photoreceptors and rod bipolar cells 


\section{Transplant}
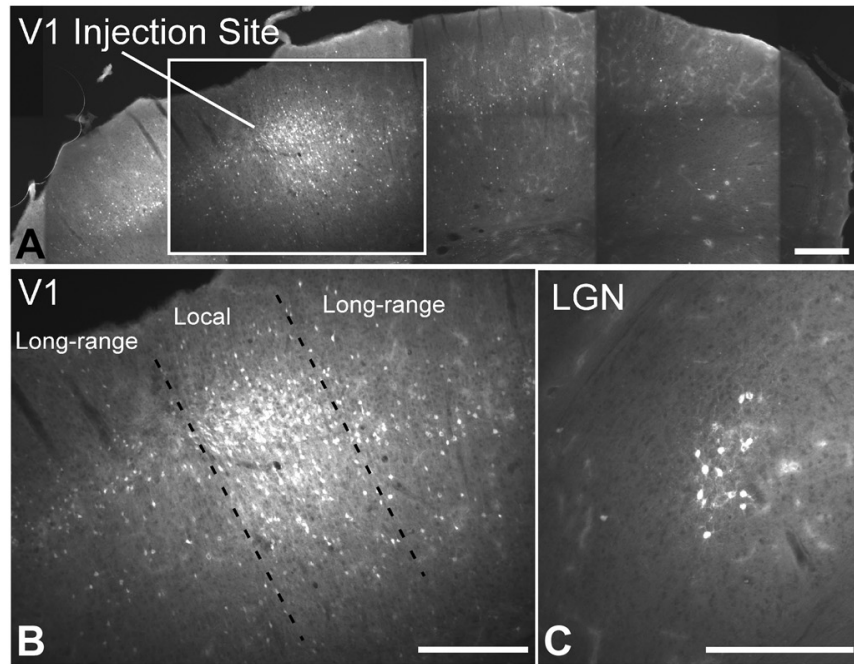

Degenerated

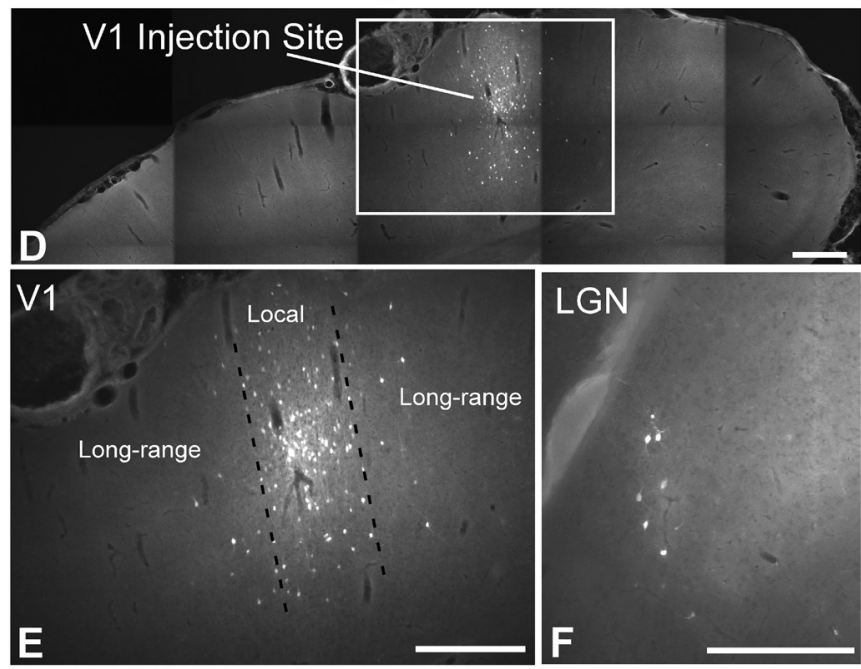

Figure 12. V1 connectivity revealed by glycoprotein-deleted GFP encoding rabies virus in transplanted and degenerated rats. $A, A V 1$ injection site in transplanted Rat R15-13 made into a region containing visually responsive neurons confirmed through recordings. $\boldsymbol{B}$, A larger magnification of injection site shown in $A$. C, Labeled neurons found in the LGN from the V1 injection in $A$. D, A V1 injection site in degenerated Rat R15- 08 that did not receive a retinal transplant. $\boldsymbol{E}$, A larger magnification of the site shown in $\boldsymbol{D}$. $\boldsymbol{F}$, Labeled neurons found in the LGN from the injection shown (D). Scale bars, $500 \mu \mathrm{m}$.

A

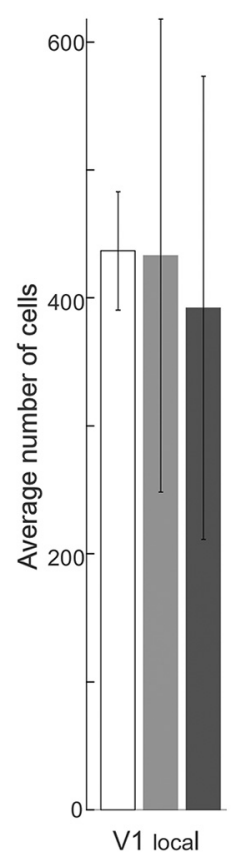

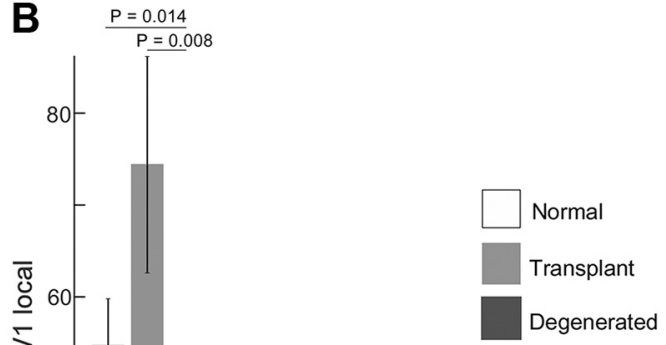

Figure 13. Distribution of V1 connections in cortex and thalamus for normal, transplanted, and degenerated rats. $\boldsymbol{A}$, The number of neurons retrogradely infected locally (within $300 \mu \mathrm{m}$ of the injection site) in V1 following injections of glycoproteindeleted rabies virus were averaged across cases within the three rat groups. $\boldsymbol{B}$, The percentage of infected neurons in the $L G N, L P$, higher visual cortex, and at long range in V1 (>300 $\mu \mathrm{m}$ from injection site) are shown for the three rat populations. For each case, percentages were derived by dividing the number of infected cells in each brain region by the number of cells found locally in V1. The same cases were used for $\boldsymbol{A}$ and $\boldsymbol{B}$; normal $(n=4)$, transplant $(n=5)$, and degenerated $(n=4)$ rat groups. $p$ values are given where significant differences between groups were found.

(Fig. 3). While we did not directly confirm synaptic connectivity in this study, elsewhere this has been confirmed repeatedly for this same type of transplant in this same rat model (Seiler et al., 2008b, 2010).

Here we found that, within months of receiving the retinal sheet transplant, V1 neurons in line-3-degenerated rats responded similarly to normal rats, revealing a high degree of selectivity to orientation, direction, spatial and temporal frequency, and contrast. In degenerated rats that did not receive a transplant, significantly fewer neurons were visually responsive and exhibited poor selectivity to all stimulus categories. This is consistent with other studies using nontransplanted line-3 rats where visual stimuli did not elicit a response in most neurons of V1 (Chen et al., 2016) and the superior colliculus (Thomas et al., 2004; Seiler et al., 2008a, b, 2017; Yang et al., 2010). To be clear, these studies, as well as ours, do report some visually responsive neurons in degenerated rats. This is likely due to some remaining cones, which have been detected as late as P90 in line-3 rats (Ray et al., 2010).

The number of visually responsive cells in transplanted rats was higher than in degenerated rats, but lower than in normal rats. Nevertheless, responsive neurons were highly selective, indicating a good degree of normal visual function. Furthermore, the location of nonresponsive neurons correlated with retinotopic regions of visual cortex that lay at the fringe or outside of the region covered by the retinal sheet transplant. Similar results in response to flashes of light were reported for neurons in the superior colliculus (Thomas et al., 2004; Seiler et al., 2008a,b, 2017; Yang et al., 2010). This indicates that generation of visual responses ise due to the transplant itself; and, furthermore, that more complete recovery of V1 function would be possible through transplants of sheets covering more retinal area. There is a possibility that transplants led to neuroprotection of 
the remaining host photoreceptors, which also contributed to improved cortical responses. However, studies using line-3 rats have found that remaining host photoreceptors were similar in number regardless of proximity to the fetal tissue graft, suggesting that there is not a neuroprotective effect (Seiler et al., 2008a, 2017).

Another of our findings was that response latency was longer for transplanted rat V1 neurons compared with normal rats. A similar increase in latency from normal rats was found using line-3 rats while recording from the superior colliculus (Yang et al., 2010), which shows that the lag is not exclusive to cortical neurons. Possible reasons for the increased latency include that the summing of inputs from photoreceptors in the transplanted retina through to ganglion cells of the original retina has either longer to travel due to the added layer of retina or longer to summate due to a weaker level of photoreceptor output. Nevertheless, the delay does not seem to perturb selectivity of V1 neurons in transplanted rats as we observed.

Tracing with monosynaptic rabies virus demonstrated that feedforward inputs from visual thalamus, connectivity within V1, and feedback from higher visual areas were present in degenerated rats, but overall to a lesser extent than transplanted and normal rats. This is important because it reveals that underlying visual cortical circuitry is available for retinal sheet transplants to engage. Furthermore, our findings show that transplantation restores the circuitry to a level comparable with normal rats.

Compared with other existing retrograde tracers, the glycoprotein-deleted rabies virus is more sensitive. It fills the entirety of each infected cell with fluorescent protein, enabling more reliable identification (Wickersham et al., 2007a,b; Connolly et al., 2012; Y. J. Liu et al., 2013; Negwer et al., 2017; Lean et al., 2018). It also infects specifically through synaptic terminals (Lafon, 2005) and therefore does not get taken up by axons of passage, unlike standard retrograde and anterograde tracers (Ugolini, 1995; Kelly and Strick, 2000; Nassi et al., 2006; Callaway, 2008; Lyon et al., 2010; Lyon and Rabideau, 2012). In this way, axons passing through or near V1, if abnormally in degenerated rats, would not be infected.

From V1 injections, we found that degeneration had the greatest effect on long-range connectivity within V1 and that transplantation was able to restore these connections to a more normal level. There were no significant differences in local V1 connections, feedback from higher visual cortex, or the LP. Local V1 connections, within $300 \mu \mathrm{m}$, were greatest in number in all rats, consistent with reports in other species showing that the majority of V1 connectivity arises from neighboring cells (Burkhalter, 1989; Lyon and Kaas, 2002a,b; Mariño et al., 2005; Anderson and Martin, 2009; Y. J. Liu et al., 2013). Remarkably, LGN projections to V1 were in place, even in degenerated rats. Although significantly fewer compared with transplanted and normal rats, this primary retinal relay remained despite several months without significant retinal input.

These anatomical results represent a first pass in describing the circuitry differences between degenerated, transplanted, and normal rats. Because connectivity can vary from injection to injection, we tried to normalize by converting to percentage connectivity. However, new technology is emerging where connectivity can be related to specific numbers of starter cells, specific cell types, and specific cortical layers in V1 (Y. J. Liu et al., 2013; Kim et al., 2015; Wall et al., 2016), which will allow for more detailed and representative comparisons of brainwide connectivity in future studies.
In conclusion, our results show that vision can be remedied and normal circuitry and function provided at the level of cortical processing in animal models of severe retinal degeneration. Fetal retinal sheet transplants can be successfully incorporated into the host tissue to deliver the signals necessary for highly selective visual responses in cortex. These results show the potential this approach may have to restore vision in people suffering from late-stage macular degeneration or retinitis pigmentosa.

\section{References}

Albrecht DG, Hamilton DB (1982) Striate cortex of monkey and cat: contrast response function. J Neurophysiol 48:217-237. CrossRef Medline

Alitto HJ, Usrey WM (2004) Influence of contrast on orientation and temporal frequency tuning in ferret primary visual cortex. J Neurophysiol 91:2797-2808. CrossRef Medline

Alitto HJ, Usrey WM (2008) Origin and dynamics of extraclassical suppression in the lateral geniculate nucleus of the macaque monkey. Neuron 57:135-146. CrossRef Medline

Anderson JC, Martin KA (2009) The synaptic connections between cortical areas v1 and v2 in macaque monkey. J Neurosci 29:11283-11293. CrossRef Medline

Aramant RB, Seiler MJ (2002) Retinal transplantation: advantages of intact fetal sheets. Prog Retin Eye Res 21:57-73. CrossRef Medline

Berson EL, Rosner B, Sandberg MA, Weigel-DiFranco C, Moser A, Brockhurst RJ, Hayes KC, Johnson CA, Anderson EJ, Gaudio AR, Willett WC, Schaefer EJ (2004) Clinical trial of docosahexaenoic acid in patients with retinitis pigmentosa receiving vitamin A treatment. Arch Ophthalmol 122:1297-1305. CrossRef Medline

Bertolotti E, Neri A, Camparini M, Macaluso C, Marigo V (2014) Stem cells as source for retinal pigment epithelium transplantation. Prog Retin Eye Res 42:130-144. CrossRef Medline

Brainard DH (1997) The psychophysics toolbox. Spat Vis 10:433-436. CrossRef Medline

Burkhalter A (1989) Intrinsic connections of rat primary visual cortex: laminar organization of axonal projections. J Comp Neurol 279:171-186. CrossRef Medline

Callaway EM (2008) Transneuronal circuit tracing with neurotropic viruses. Curr Opin Neurobiol 18:617-623. CrossRef Medline

Carandini M, Ferster D (2000) Membrane potential and firing rate in cat primary visual cortex. J Neurosci 20:470-484. CrossRef Medline

Cavanaugh JR, Bair W, Movshon JA (2002) Selectivity and spatial distribution of signals from the receptive field surround in macaque V1 neurons. J Neurophysiol 88:2547-2556. CrossRef Medline

Chen K, Wang Y, Liang X, Zhang Y, Ng TK, Chan LL (2016) Electrophysiology alterations in primary visual cortex neurons of retinal degeneration (S334ter-line-3) rats. Sci Rep 6:26793. CrossRef Medline

Coffey PJ, Girman S, Wang SM, Hetherington L, Keegan DJ, Adamson P, Greenwood J, Lund RD (2002) Long-term preservation of cortically dependent visual function in RCS rats by transplantation. Nat Neurosci 5:53-56. CrossRef Medline

Connolly JD, Hashemi-Nezhad M, Lyon DC (2012) Parallel feedback pathways in visual cortex of cats revealed through a modified rabies virus. J Comp Neurol 520:988-1004. CrossRef Medline

DeAngelis GC, Ohzawa I, Freeman RD (1993) Spatiotemporal organization of simple-cell receptive fields in the cat's striate cortex. II. Linearity of temporal and spatial summation. J Neurophysiol 69:1118-1135. CrossRef Medline

Gias C, Vugler A, Lawrence J, Carr AJ, Chen LL, Ahmado A, Semo M, Coffey PJ (2011) Degeneration of cortical function in the royal college of surgeons rat. Vision Res 51:2176-2185. CrossRef Medline

Girman SV, Sauve Y, Lund, RD (1999) Receptive field properties of single neurons in rat primary visual cortex. J Neurophysiol 82:301-311. CrossRef Medline

Girman SV, Wang S, Lund RD (2003) Cortical visual functions can be preserved by subretinal RPE cell grafting in RCS rats. Vision Res 43:18171827. CrossRef Medline

Glickfeld LL, Olsen SR (2017) Higher-order areas of the mouse visual cortex. Annu Rev Vis Sci 3:251-273. CrossRef Medline

Glickfeld LL, Histed MH, Maunsell JH (2013) Mouse primary visual cortex is used to detect both orientation and contrast changes. J Neurosci 33: 19416-19422. CrossRef Medline

Glickfeld LL, Reid RC, Andermann ML (2014) A mouse model of higher 
visual cortical function. Curr Opin Neurobiol 24:28-33. CrossRef Medline

Hashemi-Nezhad M, Lyon DC (2012) Orientation tuning of the suppressive extraclassical surround depends on intrinsic organization of V1. Cereb Cortex 22:308-326. CrossRef Medline

Hombrebueno JR, Tsai MM, Kim HL, De Juan J, Grzywacz NM, Lee EJ (2010) Morphological changes of short-wavelength cones in the developing S334ter-3 transgenic rat. Brain Res 1321:60-66. CrossRef Medline

Hubel DH, Wiesel TN (1962) Receptive fields, binocular interaction and functional architecture in the cat's visual cortex. J Physiol 160:106-154. CrossRef Medline

Kauper K, McGovern C, Sherman S, Heatherton P, Rapoza R, Stabila P, Dean B, Lee A, Borges S, Bouchard B, Tao W (2012) Two-year intraocular delivery of ciliary neurotrophic factor by encapsulated cell technology implants in patients with chronic retinal degenerative diseases. Invest Ophthalmol Vis Sci 53:7484. CrossRef Medline

Kelly RM, Strick PL (2000) Rabies as a transneuronal tracer of circuits in the central nervous system. J Neurosci Methods 103:63-71. CrossRef Medline

Kim EJ, Juavinett AL, Kyubwa EM, Jacobs MW, Callaway EM (2015) Three types of cortical layer 5 neurons that differ in brain-wide connectivity and function. Neuron 88:1253-1267. CrossRef Medline

Kisseberth WC, Brettingen NT, Lohse JK, Sandgren EP (1999) Ubiquitous expression of marker transgenes in mice and rats. Dev Biol 214:128-138. CrossRef Medline

Kleiner M, Brainard D, Pelli D, Ingling A, Murray R, Broussard C (2007) What's new in psychtoolbox-3. Perception 36:1-16. CrossRef Medline

Kobatake E, Tanaka K (1994) Neuronal selectivities to complex object features in the ventral visual pathway of the macaque cerebral cortex. J Neurophysiol 71:856-867. CrossRef Medline

Lafon M (2005) Rabies virus receptors. J Neurovirol 11:82-87. CrossRef Medline

LaVail MM, Nishikawa S, Steinberg RH, Naash MI, Duncan JL, Trautmann N, Matthes MT, Yasumura D, Lau-Villacorta C, Chen J, Peterson WM, Yang H, Flannery JG (2018) Phenotypic characterization of P23H and S334ter rhodopsin transgenic rat models of inherited retinal degeneration. Exp Eye Res 167:56-90. CrossRef Medline

Lean GA, Liu YJ, Lyon DC (2018) Cell type specific tracing of the subcortical input to primary visual cortex from the basal forebrain. J Comp Neurol. Advance online publication. Retrieved February 14, 2018. doi: 10.1002/ cne.24412.

Lipinski DM, Thake M, MacLaren RE (2013) Clinical applications of retinal gene therapy. Prog Retin Eye Res 32:22-47. CrossRef Medline

Liu YJ, Hashemi-Nezhad M, Lyon DC (2011a) Dynamics of extraclassical surround modulation in three types of V1 neurons. J Neurophysiol 105: 1306-1317. CrossRef Medline

Liu MM, Tuo J, Chan CC (2011b) Gene therapy for ocular diseases. Br J Ophthalmol 95:604-612. CrossRef Medline

Liu YJ, Ehrengruber MU, Negwer M, Shao HJ, Cetin AH, Lyon DC (2013) Tracing inputs to inhibitory or excitatory neurons of mouse and cat visual cortex with a targeted rabies virus. Curr Biol 23:1746-1755. CrossRef Medline

Liu YJ, Hashemi-Nezhad M, Lyon DC (2015) Contrast invariance of orientation tuning in cat primary visual cortex neurons depends on stimulus size. J Physiol 19:1-28. CrossRef Medline

Liu YJ, Hashemi-Nezhad M, Lyon DC (2017) Differences in orientation tuning between pinwheel and domain neurons in primary visual cortex depend on contrast and size. Neurophotonics 4:031209. CrossRef Medline

Livingstone M, Hubel D (1988) Segregation of form, color, movement, and depth: anatomy, physiology, and perception. Science 240:740-749. CrossRef Medline

Lyon DC, Kaas JH (2002a) Evidence for a modified V3 with dorsal and ventral halves in macaque monkeys. Neuron 33:453-461. CrossRef Medline

Lyon DC, Kaas JH (2002b) Evidence from V1 connections for both dorsal and ventral subdivisions of $\mathrm{V} 3$ in three species of new world monkeys. J Comp Neurol 449:281-297. CrossRef Medline

Lyon DC, Rabideau C (2012) Lack of robust LGN label following transneuronal rabies virus injections into macaque area V4. J Comp Neurol 520: 2500-2511. CrossRef Medline

Lyon DC, Nassi JJ, Callaway EM (2010) A disynaptic relay from superior colliculus to dorsal stream visual cortex in macaque monkey. Neuron 65:270-279. CrossRef Medline

Mariño J, Schummers J, Lyon DC, Schwabe L, Beck O, Wiesing P, Obermayer K, Sur M (2005) Invariant computations in local cortical networks with balanced excitation and inhibition. Nat Neurosci 8:194-201. CrossRef Medline

Marshel JH, Garrett ME, Nauhaus I, Callaway EM (2011) Functional specialization of seven mouse visual cortical areas. Neuron 72:1040-1054. CrossRef Medline

Marshel JH, Kaye AP, Nauhaus I, Callaway EM (2012) Anterior-posterior direction opponency in the superficial mouse lateral geniculate nucleus. Neuron 76:713-720. CrossRef Medline

Martinez-Navarrete G, Seiler MJ, Aramant RB, Fernandez-Sanchez L, Pinilla I, Cuenca N (2011) Retinal degeneration in two lines of transgenic S334ter rats. Exp Eye Res 92:227-237. CrossRef Medline

Naka KI, Rushton WA (1966) S-potentials from luminosity units in the retina of fish (Cyprinidae). J Physiol 185:587-599. CrossRef Medline

Nassi JJ, Lyon DC, Callaway EM (2006) The parvocellular LGN provides a robust disynaptic input to the visual motion area MT. Neuron 50:319327. CrossRef Medline

Negwer M, Liu YJ, Schubert D, Lyon DC (2017) V1 connections reveal a series of elongated higher visual areas in the California ground squirrel, Otospermophilus beecheyi. J Comp Neurol 525:1909-1921. CrossRef Medline

Niell CM, Stryker MP (2008) Highly selective receptive fields in mouse visual cortex. J Neurosci 28:7520-7536. CrossRef Medline

Osakada F, Mori T, Cetin AH, Marshel JH, Virgen B, Callaway EM (2011) New rabies virus variants for monitoring and manipulating activity and gene expression in defined neural circuits. Neuron 71:617-631. CrossRef Medline

Paxinos G, Watson C (2001) The rat brain in stereotaxic coordinates. Burlington, MA: Academic Press.

Pelli DG (1997) The VideoToolbox software for visual psychophysics: transforming numbers into movies. Spat Vis 10:437-442. CrossRef Medline

Przybyszewski AW, Kagan I, Snodderly DM (2014) Primate area V1: largest response gain for receptive fields in the straight-ahead direction. Neuroreport 25:1109-1115. CrossRef Medline

Radtke ND, Aramant RB, Petry HM, Green PT, Pidwell DJ, Seiler MJ (2008) Vision improvement in retinal degeneration patients by implantation of retina together with retinal pigment epithelium. Am J Ophthalmol 146: 172-182.e1. CrossRef Medline

Ray A, Sun GJ, Chan L, Grzywacz NM, Weiland J, Lee EJ (2010) Morphological alterations in retinal neurons in the S334ter-line3 transgenic rat. Cell Tissue Res 339:481-491. CrossRef Medline

Reid RC, Alonso JM (1996) The processing and encoding of information in the visual cortex. Curr Opin Neurobiol 6:475-480. CrossRef Medline

Sagdullaev BT, Aramant RB, Seiler MJ, Woch G, McCall MA (2003) Retinal transplantation-induced recovery of retinotectal visual function in a rodent model of retinitis pigmentosa. Invest Ophthalmol Vis Sci 44:16861695. CrossRef Medline

Sceniak MP, Chatterjee S, Callaway EM (2006) Visual spatial summation in macaque geniculocortical afferents. J Neurophysiol 96:3474-3484. CrossRef Medline

Schwartz SD, Regillo CD, Lam BL, Eliott D, Rosenfeld PJ, Gregori NZ, Hubschman JP, Davis JL, Heilwell G, Spirn M, Maguire J, Gay R, Bateman J, Ostrick RM, Morris D, Vincent M, Anglade E, Del Priore LV, Lanza R (2015) Human embryonic stem cell-derived retinal pigment epithelium in patients with age-related macular degeneration and Stargardt's macular dystrophy: follow-up of two open-label phase 1/2 studies. Lancet 385: 509-516. CrossRef Medline

Seiler MJ, Aramant RB (1998) Intact sheets of fetal retina transplanted to restore damaged rat retinas. Invest Ophthalmol Vis Sci 39:2121-2131. Medline

Seiler MJ, Aramant RB, Ball SL (1999) Photoreceptor function of retinal transplants implicated by light-dark shift of S-antigen and rod transducin. Vision Res 39:2589-2596. CrossRef Medline

Seiler MJ, Sagdullaev BT, Woch G, Thomas BB, Aramant RB (2005) Transsynaptic virus tracing from host brain to subretinal transplants. Eur J Neurosci 21:161-172. CrossRef Medline

Seiler MJ, Thomas BB, Chen Z, Arai S, Chadalavada S, Mahoney MJ, Sadda SR, Aramant RB (2008a) BDNF-treated retinal progenitor sheets trans- 
planted to degenerate rats: improved restoration of visual function. Exp Eye Res 86:92-104. CrossRef Medline

Seiler MJ, Thomas BB, Chen Z, Wu R, Sadda SR, Aramant RB (2008b) Retinal transplants restore visual responses: trans-synaptic tracing from visually responsive sites labels transplant neurons. Eur J Neurosci 28:208220. CrossRef Medline

Seiler MJ, Aramant RB, Thomas BB, Peng Q, Sadda SR, Keirstead HS (2010) Visual restoration and transplant connectivity in degenerate rats implanted with retinal progenitor sheets. Eur J Neurosci 31:508-520. CrossRef Medline

Seiler MJ, Aramant RB, Jones MK, Ferguson DL, Bryda EC, Keirstead HS (2014) A new immunodeficient pigmented retinal degenerate rat strain to study transplantation of human cells without immunosuppression. Graefes Arch Clin Exp Ophthalmol 252:1079-1092. CrossRef Medline

Seiler MJ, Lin RE, McLelland BT, Mathur A, Lin B, Sigman J, De Guzman AT, Kitzes LM, Aramant RB, Thomas BB (2017) Vision recovery and connectivity by fetal retinal sheet transplantation in an immunodeficient retinal degenerate rat model. Invest Ophthalmol Vis Sci 58:614-630. CrossRef Medline

Thomas BB, Seiler MJ, Sadda SR, Aramant RB (2004) Superior colliculus responses to light-preserved by transplantation in a slow degeneration rat model. Exp Eye Res 79:29-39. CrossRef Medline

Thomas BB, Aramant RB, Sadda SR, Seiler MJ (2005) Light response differences in the superior colliculus of albino and pigmented rats. Neurosci Lett 385:143-147. CrossRef Medline

Tsai Y, Lu B, Bakondi B, Girman S, Sahabian A, Sareen D, Svendsen CN, Wang S (2015) Human iPSC-derived neural progenitors preserve vision in an AMD-like model. Stem Cells 33:2537-2549. CrossRef Medline

Ugolini G (1995) Specificity of rabies virus as a transneuronal tracer of mo- tor networks: transfer from hypoglossal motoneurons to connected second-order and higher order central nervous system cell groups. J Comp Neurol 356:457-480. CrossRef Medline

Van den Bergh G, Zhang B, Arckens L, Chino YM (2010) Receptive-field properties of V1 and V2 neurons in mice and macaque monkeys. J Comp Neurol 518:2051-2070. CrossRef Medline

Wall NR, De La Parra M, Sorokin JM, Taniguchi H, Huang ZJ, Callaway EM (2016) Brain-wide maps of synaptic input to cortical interneurons. J Neurosci 36:4000-4009. CrossRef Medline

Wickersham IR, Finke S, Conzelmann KK, Callaway EM (2007a) Retrograde neuronal tracing with a deletion-mutant rabies virus. Nat Methods 4:47-49. CrossRef Medline

Wickersham IR, Lyon DC, Barnard RJ, Mori T, Finke S, Conzelmann KK, Young JA, Callaway EM (2007b) Monosynaptic restriction of transsynaptic tracing from single, genetically targeted neurons. Neuron 53:639_ 647. CrossRef Medline

Wickersham IR, Sullivan HA, Seung HS (2010) Production of glycoproteindeleted rabies viruses for monosynaptic tracing and high-level gene expression in neurons. Nat Protoc 5:595-606. CrossRef Medline

Woch G, Aramant RB, Seiler MJ, Sagdullaev BT, McCall MA (2001) Retinal transplants restore visually evoked responses in rats with photoreceptor degeneration. Invest Ophthalmol Vis Sci 42:1669-1676. Medline

Yang PB, Seiler MJ, Aramant RB, Yan F, Mahoney MJ, Kitzes LM, Keirstead HS (2010) Trophic factors GDNF and BDNF improve function of retinal sheet transplants. Exp Eye Res 91:727-738. CrossRef Medline

Zhu CL, Ji Y, Lee EJ, Grzywacz NM (2013) Spatiotemporal pattern of rod degeneration in the S334ter-line-3 rat model of retinitis pigmentosa. Cell Tissue Res 351:29-40. CrossRef Medline 